Prepared in cooperation with the Bureau of Reclamation

\title{
Dependence of Flow and Transport through the Williamson River Delta, Upper Klamath Lake, Oregon, on Wind, River Inflow, and Lake Elevation
}

Scientific Investigations Report 2012-5004 
EXAMPLE: Cover: Illustrations of largemouth bass, and yellow perch have been supplied courtesy of the Ohio State Environmental Protection Agency. 


\section{Dependence of Flow and Transport through the Williamson River Delta, Upper Klamath Lake, Oregon, on Wind, River Inflow, and Lake Elevation}

By Tamara M. Wood

Prepared in cooperation with the Bureau of Reclamation

Scientific Investigations Report 2012-5004 


\section{U.S. Department of the Interior \\ KEN SALAZAR, Secretary \\ U.S. Geological Survey \\ Marcia K. McNutt, Director}

\section{U.S. Geological Survey, Reston, Virginia 2012}

For more information on the USGS - the Federal source for science about the Earth, its natural and living resources, natural hazards, and the environment, visit http://www.usgs.gov or call 1-888-ASK-USGS.

For an overview of USGS information products, including maps, imagery, and publications, visit http://www.usgs.gov/pubprod

To order this and other USGS information products, visit http://store.usgs.gov

Any use of trade, product, or firm names is for descriptive purposes only and does not imply endorsement by the U.S. Government.

Although this report is in the public domain, permission must be secured from the individual copyright owners to reproduce any copyrighted materials contained within this report.

Suggested citation:

Wood, T.M., 2012, Dependence of flow and transport through the Williamson River Delta, Upper Klamath Lake, Oregon, on wind, river inflow, and lake elevation: U.S. Geological Survey Scientific Investigations Report 2012-5004, $32 \mathrm{p}$. 


\section{Contents}

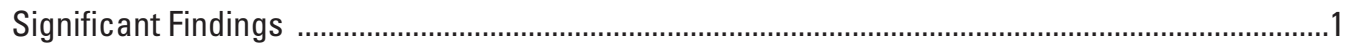

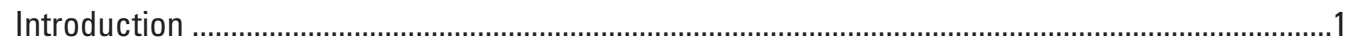

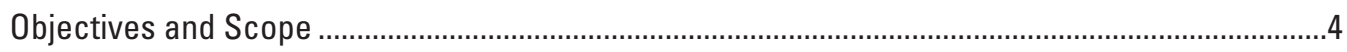

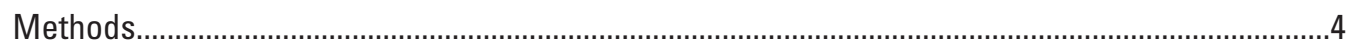

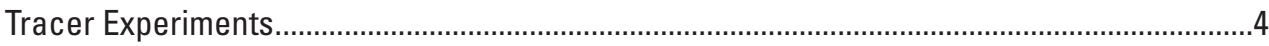

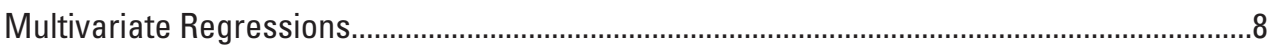

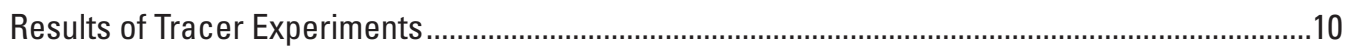

Dependence of Flow through the Delta on Wind ...............................................................11

Dependence of Flow through the Delta on Inflow and Elevation ............................................14

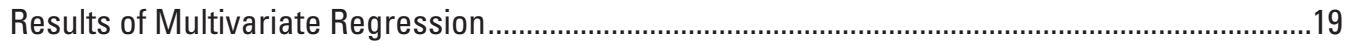

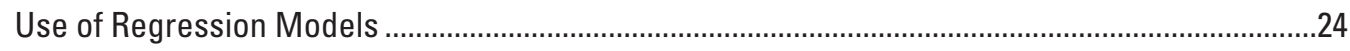

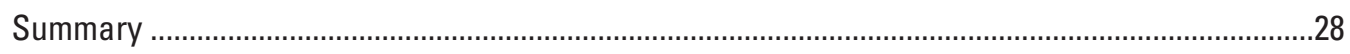

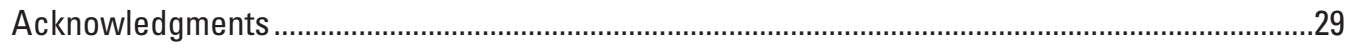

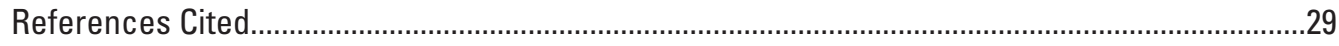

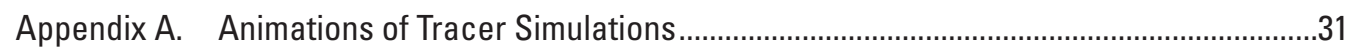




\section{Figures}

Figure 1. Map showing Upper Klamath and Agency Lakes, and the Williamson River Delta, Oregon.

Figure 2. Bathymetric maps showing lake elevation data converted to depths relative to full pool for the restored Tulana and Goose Bay areas of the Williamson River Delta and the resulting numerical grid after merging with the existing model of Upper Klamath and Agency Lakes, Oregon

Figure 3. Drawing showing initial values of tracers used in the tracer experiments within areas of Upper Klamath and Agency Lakes and the Williamson River Delta, Oregon.

Figure 4. Graph showing time series of the 75th percentile wind observations at meteorological site Williamson River West (WRW-MET), Upper Klamath Lake, Oregon, at 5-day intervals between April 27 and September 29, 2008

Figure 5. Images showing the last frame from an animation of the simulation of the Goose Bay, Williamson River, and Tulana tracer under strong northwest wind conditions as measured on May 22, 2008, at Upper Klamath Lake, Oregon, starting at 1:00 AM and ending at 12:00 PM

Figure 6. Graph showing the total fraction of Goose Bay and Tulana water replaced in 1 day, and the partial fraction of Goose Bay and Tulana water replaced with water from the Williamson River in 1 day, Upper Klamath Lake, Oregon, based on numerical tracer experiments

Figure 7. Graph showing theoretical water replacement time for Goose Bay and Tulana in Upper Klamath Lake, Oregon, based on numerical tracer experiments

Figure 8. Graphs showing replacement rate of water calculated over 1 day in Goose Bay and Tulana, Upper Klamath Lake, Oregon, based on numerical tracer experiments

Figure 9. Graphs showing replacement rate of water calculated over 1 day in Goose Bay and Tulana, Upper Klamath Lake, Oregon, based on numerical tracer experiments

Figure 10. Graphs showing one-day partial replacement rate of water in Goose Bay and Tulana with Williamson River water, Upper Klamath Lake, Oregon, based on numerical tracer experiments

Figure 11. Graphs showing one-day partial replacement rate of water in Goose Bay and Tulana with Williamson River water, Upper Klamath Lake, Oregon, based on numerical tracer experiments

Figure 12. Scatter plots of best regressions for each dependent variable, where the dependent variables were based on numerical tracer experiments and calculations made at 5-day intervals between April 27 and October 9, 2008

Figure 13. Contour plots of the best regressions for Goose Bay total replacement rate $(R R-G B)$ and partial replacement rate $(R R-G B W W R)$, Upper Klamath Lake, Oregon, as a function of values of the independent variables lake elevation and Williamson River inflow 


\section{Figures-Continued}

Figure 14. Contour plots of the best regressions for Tulana replacement rate (RR-TUL) and partial replacement rate (RR-TULWWR), Upper Klamath Lake, Oregon, as a function of values of the independent variables lake elevation and Williamson

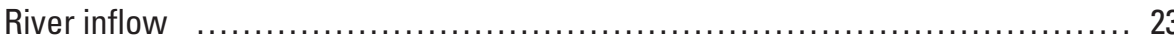

Figure 15. Contour plots of the best regressions for the partial replacement rate in Goose Bay $(R R-G B W W R)$, and Tulana (RR-TULwWR), Upper Klamath Lake, Oregon, as a function of values of the independent variables magnitude of the east-west and north-south wind component at the Williamson River West meteorological station

Figure 16. Graphs showing total rate of replacement in Goose Bay and Tulana in Upper Klamath Lake, Oregon, partial replacement rate of water in Goose Bay and Tulana with Williamson River water, and theoretical replacement time of the water in Goose Bay and Tulana, as a function of lake elevation, as calculated with multi-variate regression models

Figure 17. Graphs showing Total rate of replacement in Goose Bay and Tulana in Upper Klamath Lake, Oregon, partial replacement rate of water in Goose Bay and Tulana with Williamson River water, and estimated contribution of benthic fluxes to orthophosphate concentration in Goose Bay and Tulana as a function of lake elevation, as calculated with multi-variate regression models

\section{Tables}

Table 1. Percentiles of the annual mean and annual peak flows at the Williamson River near Chiloquin, Oregon, stream-gaging station (11052500) for the period of record, 1918-2009

Table 2. Definitions of dependent and independent variables used in the regression models

Table 3. Summary of the best regression models for dependent variables 20 


\section{Conversion Factors and Datums}

Inch/Pound to SI

\begin{tabular}{lcc}
\hline Multiply & By & To obtain \\
\hline foot $(\mathrm{ft})$ & Length & meter $(\mathrm{m})$ \\
\hline & 0.3048 & \\
\hline cubic foot per second $\left(\mathrm{ft}^{3} / \mathrm{s}\right)$ & Flow rate & cubic meter per second $\left(\mathrm{m}^{3} / \mathrm{s}\right)$ \\
\hline
\end{tabular}

SI to Inch/Pound

\begin{tabular}{|c|c|c|}
\hline Multiply & By & To obtain \\
\hline \multicolumn{3}{|c|}{ Length } \\
\hline meter (m) & 3.281 & foot (ft) \\
\hline kilometer (km) & 0.6214 & mile (mi) \\
\hline \multicolumn{3}{|c|}{ Area } \\
\hline square kilometer $\left(\mathrm{km}^{2}\right)$ & 247.1 & acre \\
\hline square kilometer $\left(\mathrm{km}^{2}\right)$ & 0.3861 & square mile $\left(\mathrm{mi}^{2}\right)$ \\
\hline hectare (ha) & 0.003861 & square mile $\left(\mathrm{mi}^{2}\right)$ \\
\hline \multicolumn{3}{|c|}{ Volume } \\
\hline cubic meter $\left(\mathrm{m}^{3}\right)$ & 35.31 & cubic foot $\left(\mathrm{ft}^{3}\right)$ \\
\hline cubic meter $\left(\mathrm{m}^{3}\right)$ & 1.308 & cubic yard $\left(\mathrm{yd}^{3}\right)$ \\
\hline \multicolumn{3}{|c|}{ Flow rate } \\
\hline meter per second $(\mathrm{m} / \mathrm{s})$ & 3.281 & foot per second (ft/s) \\
\hline cubic meter per second $\left(\mathrm{m}^{3} / \mathrm{s}\right)$ & 35.31 & cubic foot per second $\left(\mathrm{ft}^{3} / \mathrm{s}\right)$ \\
\hline cubic meter per day $\left(\mathrm{m}^{3} / \mathrm{d}\right)$ & 35.31 & cubic foot per day (ftº \\
\hline \multicolumn{3}{|c|}{ Mass } \\
\hline kilogram (kg) & 2.205 & pound avoirdupois (lb) \\
\hline
\end{tabular}

Concentrations of chemical constituents in water are given either in milligrams per liter (mg/L) or micrograms per liter ( $\mu \mathrm{g} / \mathrm{L})$.

Both English and metric units are used in this report for the convenience of all readers. The results are presented in metric units only, with the exception of lake elevation which, because of the familiarity of English units to scientists and managers who work in the Upper Klamath Basin, is presented in feet. The regression models use metric units.

Datums

Vertical coordinate information is referenced to the Bureau of Reclamation datum, which is 1.78 feet above National Geodetic Vertical Datum of 1929 (NGVD 29).

Horizontal coordinate information is referenced to the North American Datum of 1927 (NAD 27). 


\title{
Dependence of Flow and Transport through the Williamson River Delta, Upper Klamath Lake, Oregon, on Wind, River Inflow, and Lake Elevation
}

\author{
By Tamara M. Wood
}

\section{Significant Findings}

The hydrodynamic model of Upper Klamath and Agency Lakes, Oregon, was used to run 384 realizations of a numerical tracer experiment in order to understand the relative effects of wind, lake elevation, and Williamson River inflow on flow and transport (the movement of water and passively transported constituents) through the Williamson River Delta. Significant findings from this study include:

- The replacement rate of water increased in Tulana and Goose Bay with increasing lake elevation, Williamson River inflow, and wind speed.

- The fraction of Williamson River inflow passing through either side of the Delta increased with lake elevation and Williamson River inflow.

- The partial replacement rate of water in Goose Bay with water from the Williamson River increased with wind speed.

- The partial replacement rate of water in Tulana with water from the Williamson River decreased with wind speed.

- Strong wind forcing at the water surface caused more of the Williamson River inflow to pass through Goose Bay than through Tulana.

- Westerly to northwesterly winds result in more of the Williamson River inflow passing through the Goose Bay side of the Delta than through the Tulana side.

- Regression models developed from the tracer experiments can be used to quantify the dependencies between transport and the independent variables to obtain rough estimates of useful quantities such as residence time and steady-state solute concentrations.

\section{Introduction}

Upper Klamath and Agency Lakes in south-central Oregon constitute a shallow lake system with a large surface area (average depth $2.8 \mathrm{~m}$ and surface area $230 \mathrm{~km}^{2}$, fig. 1). As such, the currents in the system are primarily wind-driven. The lakes are situated in the Klamath structural graben, and under prevailing conditions, the westerly to northwesterly winds that blow over the northern part of Upper Klamath Lake are largely constrained by the surrounding topography to a north-northwesterly direction over the lower two-thirds of the lake. The resulting circulation pattern is a clockwise gyre around Upper Klamath Lake (Wood and others, 2006). The largest tributary to the system is the Williamson River, which enters Upper Klamath Lake along the northern shoreline (fig. 1); a smaller tributary is the Wood River, which enters at the northern end of Agency Lake. Lake surface elevations are regulated by the Link River Dam at the southern end of the lake, which is operated by the Bureau of Reclamation. During the summer months, lake elevation declines due to a combination of reduced inflows, evaporation, and downstream diversions to meet irrigation demands and instream flow requirements of the National Marine Fisheries Service for coho salmon in the Klamath River. As a result, in most years lake elevation declines by about $1 \mathrm{~m}$ (3.3 ft) between June 1 and September 1.

Prior to 2008, Agency and Upper Klamath Lakes were two distinct water bodies connected by a narrow channel called Agency Straits. Starting in 2008, the Williamson River restoration project, undertaken by The Nature Conservancy as owner of the property where the Williamson River enters Upper Klamath Lake, transformed the lower $3 \mathrm{mi}$ of the river. Between 2008 and 2009, a series of breaches through levees on both sides of the river channel and through levees surrounding previously drained wetlands on the northwest and southeast side of the channel reconnected the Williamson River with 3,000 ha of land that, prior to the 1940s, had 


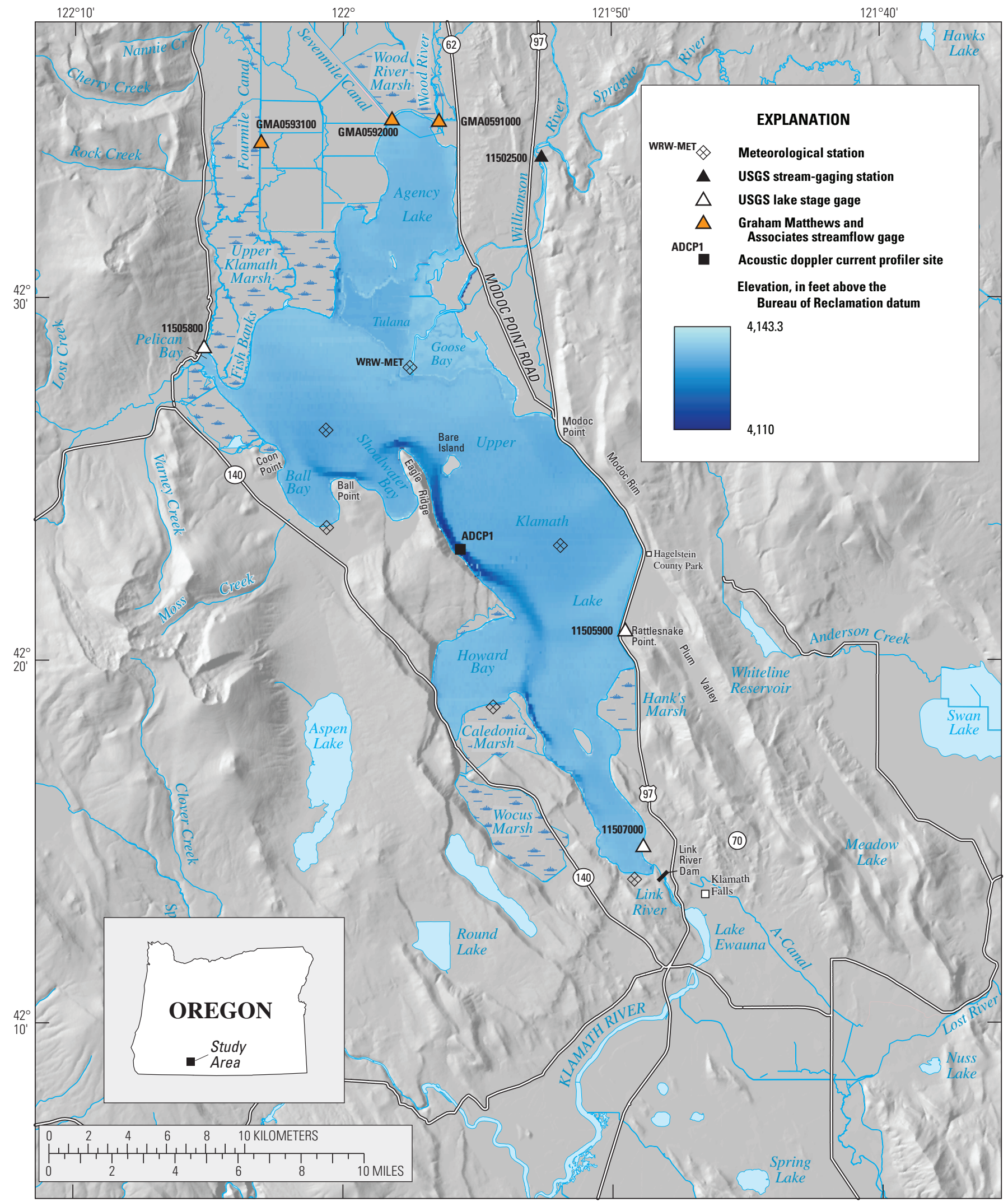

Base modified from USGS and other digital sources, various scales.

Coordinate system is UTM, Zone 10N; North American Datum of 1927.

Figure 1. Upper Klamath and Agency Lakes, and the Williamson River Delta, Oregon. 
composed the wetlands of the Williamson River Delta (hereafter referred to as the Delta [fig. 1]). Historically, these wetlands had functions that enhanced both the water quality and the ecology of Upper Klamath Lake, notably among them retaining nutrients and providing rearing habitat for larval fish. Sub-populations of the threatened Lost River and shortnose suckers, endemic to Upper Klamath Lake, spawn in the Williamson River system in early spring. After emerging from the gravel at the spawning grounds, larvae drift downstream at night with the river flow (Ellsworth and others, 2008 and 2009). Prior to restoration, all of these larvae drifted directly into Upper Klamath Lake. It is anticipated that the restored wetlands will lengthen the time it takes for most of the larvae to enter Upper Klamath Lake, and provide better conditions in terms of food availability and predator protection for larval growth and survival before they finally enter the lake.

The goal of the restoration project is to restore the historical functions of the wetlands over time, and because maximizing the connection between the River, the Delta, and Upper Klamath Lake was critical to realizing this goal, the project was designed with this in mind. Modeling scenarios using the two-dimensional MIKE 21 hydrodynamic model (DHI Water and Environment, 2002) were used to select locations for the levee breaches and channel modifications that would maximize the amount of flow leaving the Williamson River channel to flow through either the northwest side of the Delta (Tulana) or the southeast side of the Delta (Goose Bay) (Daraio and others, 2004). The scope of this study, as a matter of practical necessity, was primarily limited to simulating the flow through the Delta at one moderately high Williamson River flow $\left(2,070 \mathrm{ft}^{3} / \mathrm{s}\right.$, representing the 1.5 -year flood) and a lake elevation approaching full pool (4,143 ft, compared to a full pool elevation of 4,143.3 ft). Additionally, the scope of the study was limited in two other important ways: wind forcing at the water surface was not considered and, because of this and the location of the downstream boundaries in Agency and Upper Klamath Lakes, the influence of the large wind-driven circulation of those lakes on flow through the Delta could not be considered.

Subsequent to the work by Daraio and others (2004), a three-dimensional hydrodynamic, heat, and transport model of the entire Upper Klamath Lake/Agency Lake system using the hydrodynamic model UnTRIM (Casulli, 1999; Casulli and Cheng, 1992; Casulli and Zanolli, 2002 and 2005) was developed. The boundary of the model grid at the time of the original development reflected the situation with all levees intact, and therefore, flow from the Williamson River entered Upper Klamath Lake entirely at the mouth of the river. The model grid was subsequently modified to include Tulana within the model boundaries, which was opened with explosive breaching of the levees on October 30, 2007, in the first phase of The Nature Conservancy's restoration project. That modified version of the model grid was used to investigate the probable effect of the construction of a large offstream storage project on the transport of larval fish through the Tulana side of the Delta (Wood, 2009). The grid has since been modified again to incorporate the Goose Bay side of the Delta, which, in a second phase of The Nature Conservancy's restoration project, was reconnected to the lake with earthmoving equipment on November 18, 2008, along levees to the east of the Williamson River mouth that had previously delineated the model grid boundary. Thus, the model grid as used for the simulations in this report represents the completed changes in the landscape around the lower reach of the Williamson River that resulted from earth removal or movement associated with the Delta restoration.

This study, done in cooperation with the Bureau of Reclamation, is part of a larger modeling study of how the restoration of the Delta has affected the transport of larval suckers between the Williamson River channel upstream of restoration alterations, and the point at which they enter Upper Klamath Lake. Previous and ongoing modeling has demonstrated that lake elevation, Williamson River flow, and wind forcing all affect the movement of water and passively transported constituents through the Delta, but it is often difficult to sort out the magnitude of the dependencies when all three of these variables are changing simultaneously through a simulation. This study attempts to use a series of numerical "experiments" with the hydrodynamic model and tracers to systematically investigate the relative effects of Williamson River flow, lake elevation, and wind on the flow and transport through both sides of the Delta.

Because this study is based on the simulation of numerical tracers, the results strictly apply only to constituents that are carried passively in the flow. Therefore, the results are expected to apply generally to the problem of larval drift, but the implications of non-passive behavior for the movement of larvae through the Delta is an ongoing area of research. The results of this study will also have implications for water quality because the simulated passive transport through the Delta applies to dissolved constituents and suspended material. 


\section{Objectives and Scope}

This report presents the results of the study described above, the objective of which was: to use the hydrodynamic model of Upper Klamath and Agency Lakes to run experiments with numerical tracers while systematically varying one of three independent variables at a time (wind, lake elevation, and Williamson River inflow), and to use the results for understanding the relative effects of these three variables on flow and transport (the movement of water and passively transported constituents) through both sides of the Delta. An additional objective was to use the results of the experiments to develop multivariate regressions that quantitatively describe the dependence of flow and transport on wind, lake elevation, and Williamson River inflow. The regressions serve two purposes. First, they condense all the tracer experiment results into a single empirical model through which the dependencies are easily visualized, and they therefore contribute to understanding the movement of water and transported constituents through the Delta. Second, these regressions can be used by managers to generate rough but quantitative estimates of, for example, water residence time in the Delta or the rate of water movement through the boundaries of the Delta, for a given set of conditions.

The values of lake elevation and Williamson River inflows used in the tracer experiments spanned a realistic range of conditions, but practical considerations limited the number of elevation and inflow conditions to three elevations between 4,140.5 and 4,142.5 ft (1,262.0 and 1,262.6 m), and the number of inflows to four between 530 and $3,531 \mathrm{ft}^{3} / \mathrm{s}$ (15 and $100 \mathrm{~m}^{3} / \mathrm{s}$ ). For the same reason, it was not feasible to run the tracer experiments with all possible realistic wind configurations. Instead, an attempt was made to cover a reasonable range by running the tracer experiments at 5-day intervals between April and September 2008. This resulted in 32 distinct wind scenarios that were used as a forcing function in the tracer experiments.

\section{Methods}

Tracer experiments were designed such that only one of the three variables of interest (wind forcing, Williamson River inflow, and lake elevation) was varied at one time. The wind forcing was varied in a realistic way by running 1-day simulations at 5-day intervals using continuous records of wind speed and direction measured between April 27 and September 30, 2008, while inflow and lake elevation were held constant. The 1-day time period was selected because the wind, although not constant, can be effectively characterized in terms of speed and direction over that time period; over longer time periods the wind variability can make it difficult to define a characteristic wind vector for the purposes of relating the wind forcing to the simulation results. Because continuous records of the wind forcing were used, each simulation also incorporates a realistic set of antecedent conditions. The entire April to September set of simulations was repeated for each value of inflow and lake elevation. The result was 384 tracer simulations (32 wind scenarios times 3 lake elevations times 4 values of Williamson River inflow).

To quantify the results, two tracers were used to track the movement of water into and out of Tulana and Goose Bay and a third tracer was used to track the movement of water from the Williamson River into Tulana and Goose Bay. The amount of each of the first two tracers that left the Delta was calculated to determine a "total replacement rate" of water within each section of the Delta. The amount of the third tracer that entered the Delta was calculated to determine a "partial replacement rate" of water within each section of the Delta with water from the Williamson River. These total and partial replacement rates were used as dependent variables for building empirical regression models that used wind, lake elevation, and Williamson River inflow as independent variables.

\section{Tracer Experiments}

The hydrodynamic model of Upper Klamath and Agency Lakes was built on the UnTRIM computational core (Casulli and Cheng, 1992; Casulli, 1999; Casulli and Zanolli, 2002 and 2005). UnTRIM uses a semi-implicit, finite difference solution method to solve the governing equations for mass and momentum conservation on an orthogonal, unstructured, numerical grid. The advantage of this type of grid is that the size of the polygons that make up the grid vary over the domain in response to the local rate-of-change in the bathymetry, and it also allows for a shoreline-fitting boundary. The description of the process of calibrating and validating the three-dimensional UnTRIM model of Upper Klamath and Agency Lakes with data from 2005 and 2006 is described in Wood and others (2008). A one-layer version of the UnTRIM hydrodynamic model of the lake described in Wood and others (2008) was used to speed computation time. The use of a one-layer model removes the effects of water temperature (and therefore density) on the flow. These effects are important for understanding the transport of some water quality constituents, particularly dissolved oxygen and buoyant cyanobacteria (Wood and others, 2006, 2008). In this case, because the primary interest is the movement of water through the Delta, and the flow is expected to be well-described by two dimensions, the benefit of being able to run many more simulations in the available time outweighs the loss of accuracy that occurs by using a one-layer model. The one-layer model was recalibrated to velocity data collected with an acoustic Doppler current profiler at site ADCP1 in 
the middle of the trench (fig. 1) during 2007, using a grid that conformed to the shorelines of the lake at that time, prior to the breaching of the levees around Tulana.

The tracer simulations used for this report were generated using a numerical grid that incorporated the land inside the levees on both the Tulana and Goose Bay side of the Williamson River channel, as well as the channel itself up to approximately the location of the Modoc Point Road bridge (river kilometer 7.4). A Manning formulation was used for the bottom friction in these new areas of the grid. A Manning's $n$ of 0.026 was used within the channel to be consistent with a calibrated one-dimensional HEC-RAS model (Graham Matthews and Associates, 2001), and a Manning's n of 0.05 was used in the Tulana and Goose Bay areas of the Delta, also consistent with Graham Matthews and Associates (2001). These bottom friction roughness coefficients also are consistent with those used in the MIKE-21 model that was used to develop the project design (Daraio and others, 2004).

The unstructured orthogonal grid used in the UnTRIM model is particularly well-suited to describing the small scale features and complicated boundaries associated with the Williamson River channel and the various levees remaining around the channel and the Delta. The elevations within the Delta were obtained from a composite of data interpolated to a grid with $100 \mathrm{ft}$ horizontal spacing (L. Friend, ZCS Engineering, Inc., written commun., 2009). The grid was built from pre-project survey data in combination with the engineered design modifications for the project, then modified with additional surveys to collect data where the design elevations differed from the "as-built" elevations. These data were used to generate the bathymetry data in the new Williamson River and Delta areas of the grid, which were then merged into the existing grid for the rest of the lake (fig. 2).

The boundary conditions that are needed to run the model include the wind forcing at the surface and inflows at the Williamson and Wood Rivers, as well as the outflow at the Link River boundary, which, in the model, is the sum of the outflow at the Link River Dam and the irrigation withdrawals at the A-canal. The wind forcing was obtained from a spatial interpolation of 10-minute data from six meteorological sites (fig. 1), as described in Wood and others (2008).

The number of model simulations was limited by practical considerations, and, consequently, three values of flow and lake elevation were considered. The maximum range in lake elevation relevant to this study is between full pool at 4,143.3 $\mathrm{ft}(1,262.9 \mathrm{~m})$ and the elevation of the sills where the breaches in the levees were made at $4,139 \mathrm{ft}$ $(1,261.6 \mathrm{~m})$. Within that range, values of 4,140.5, 4,141.5, and 4,142.5 ft (1,262.0, 1,262.3, and 1,262.6 m) were selected for model runs. The lake elevation constraint was implemented in the model simulations by specifying an initial lake elevation throughout the model domain at one of the three elevation values selected for model runs, and then specifying time-invariant tributary inflows and outflows to the model domain. Evaporation and precipitation was set to zero, and the single outflow at the Link River was defined to be the sum of tributary inflows at the Williamson River and Wood River. In the model, the Wood River inflow includes the Sevenmile and Fourmile Canals that flow into Agency Lake. With these constraints, the simulated lake elevation remained constant, on average, through the length of the simulation; sub-daily variability on the order of several centimeters due to wind setup was superimposed on the long-term average.

The values used for the flow in the Williamson River were $530,883,1,766$, and $3,531 \mathrm{ft}^{3} / \mathrm{s}$, which correspond to $15,25,50$, and $100 \mathrm{~m}^{3} / \mathrm{s}$, respectively. These values span most of the large range in flows that could be expected in the Williamson River, but the mid-range values are more probable. In order to put these values into context, percentiles of the distribution of annual means and annual peak flows at the Williamson River USGS stream-gaging station (11502500) are provided in table 1. The inflows into Agency Lake at the Wood River, including flows from Sevenmile and Fourmile Canals, were calculated as 0.3 times the flows in the Williamson River. This was the May average of the ratio of the sum of the Wood, Sevenmile, and Fourmile flows to the Williamson River flow in 2004 ( 1 of 2 years in which all three inflows were recorded [Graham Matthews and Associates, unpub. data]). The month of May was relevant because the original reason for this study was to determine the connection between the Delta and the lakes during the annual spring migration of larvae out of spawning grounds. This ratio is, however, highly variable both within a single year, and in a given month between years, and the value of 0.3 is at the low end of the values measured throughout two consecutive years. Because of the variability of this ratio, sensitivity to this ratio was investigated and is reported with the results.

Three numerical tracers were used to track water leaving and entering the Tulana and Goose Bay sides of the Williamson River Delta. The first two tracers were initialized to a concentration of 10 (arbitrary units) at the start of each simulation in Tulana and Goose Bay, respectively, and zero elsewhere (fig. 3). The third tracer representing water in the Williamson River also was set to a concentration of 10 at the Williamson River upstream boundary, where all other tracers were set to a concentration of zero. Thus the third tracer tracked not only the water initially in the Williamson River channel, but also water that entered the model domain through the upstream Williamson River boundary at any time during the simulation. The total mass of each tracer within the boundaries of Tulana and Goose Bay was calculated at each time step. A 1-day total replacement rate (RR-TUL or RR-GB) for the tracers initialized within Tulana and Goose Bay was calculated at the end of the first day of each simulation as the decrease in the total mass of tracer within the Tulana and Goose Bay boundaries since the beginning of the simulation. 
A.

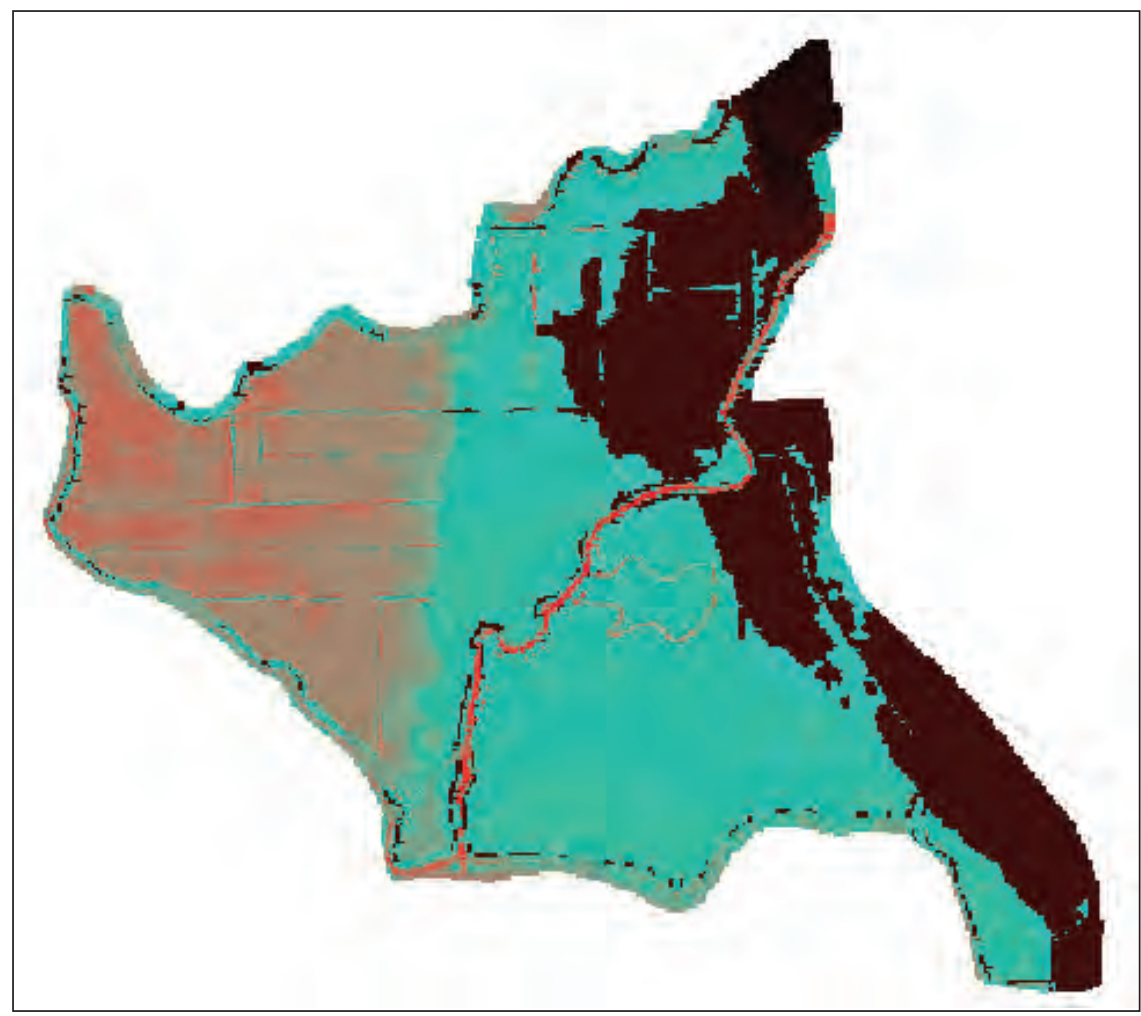

B.

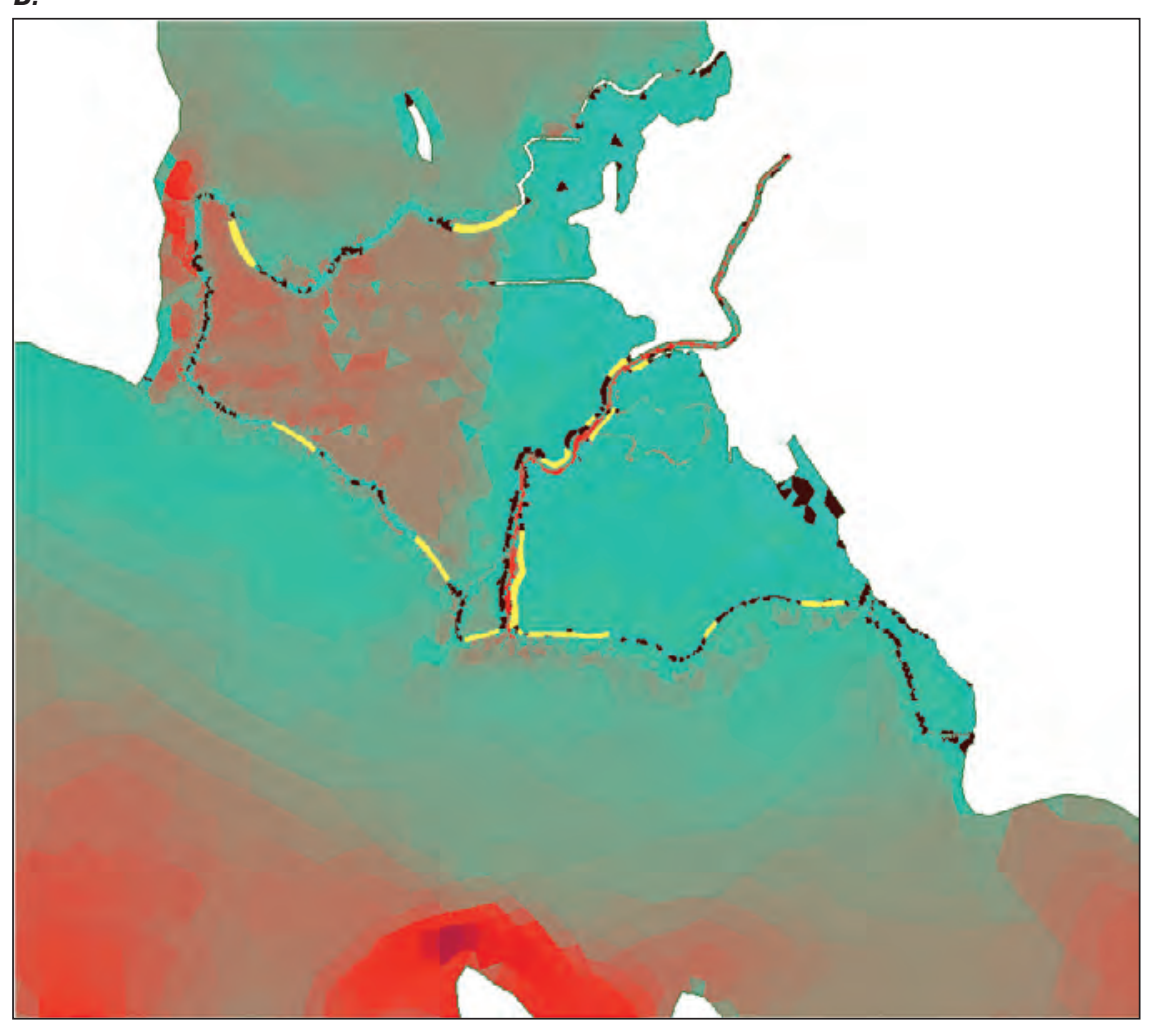

EXPLANATION

Depth relative to full pool, in meters

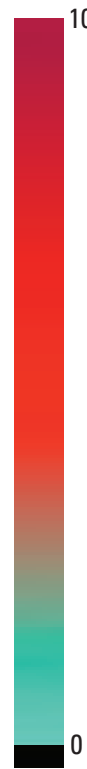

Approximate breach location, shown on panel $B$

Figure 2. Lake elevation data converted to depths relative to full pool for $(A)$ the restored Tulana and Goose Bay areas of the Williamson River Delta and $(B)$ the resulting numerical grid after merging with the existing model of Upper Klamath and Agency Lakes, Oregon. Elevation data were converted to depths relative to full pool at 4,143.3 feet (Bureau of Reclamation datum). 
Table 1. Percentiles of the annual mean and annual peak flows at the Williamson River near Chiloquin, Oregon, stream-gaging station (11052500) for the period of record, 1918-2009.

[Abbreviatons: USGS, U.S. Geological Survey; $\mathrm{ft}^{3} / \mathrm{s}$, cubic foot per second; $\mathrm{m}^{3} / \mathrm{s}$, cubic meter per second]

\begin{tabular}{|c|c|c|c|c|}
\hline Percentile & $\begin{array}{c}\text { Annual } \\
\text { mean } \\
\text { flows } \\
\left(\mathrm{ft}^{3} / \mathrm{s}\right)\end{array}$ & $\begin{array}{c}\text { Annual } \\
\text { peak } \\
\text { flows } \\
\left(\mathrm{ft}^{3} / \mathrm{s}\right)\end{array}$ & $\begin{array}{c}\text { Annual } \\
\text { mean } \\
\text { flows } \\
\left(\mathrm{m}^{3} / \mathrm{s}\right)\end{array}$ & $\begin{array}{c}\text { Annual } \\
\text { peak } \\
\text { flows } \\
\left(\mathrm{m}^{3} / \mathrm{s}\right)\end{array}$ \\
\hline 1 & 483 & 700 & 14 & 20 \\
\hline 5 & 588 & 1,090 & 17 & 31 \\
\hline 10 & 670 & 1,520 & 19 & 43 \\
\hline 25 & 743 & 1,920 & 21 & 54 \\
\hline 50 & 956 & 2,810 & 27 & 80 \\
\hline 75 & 1,263 & 4,540 & 36 & 129 \\
\hline 90 & 1,588 & 6,660 & 45 & 189 \\
\hline 95 & 1,636 & 7,660 & 46 & 217 \\
\hline 99 & 2,187 & 17,100 & 62 & 484 \\
\hline
\end{tabular}

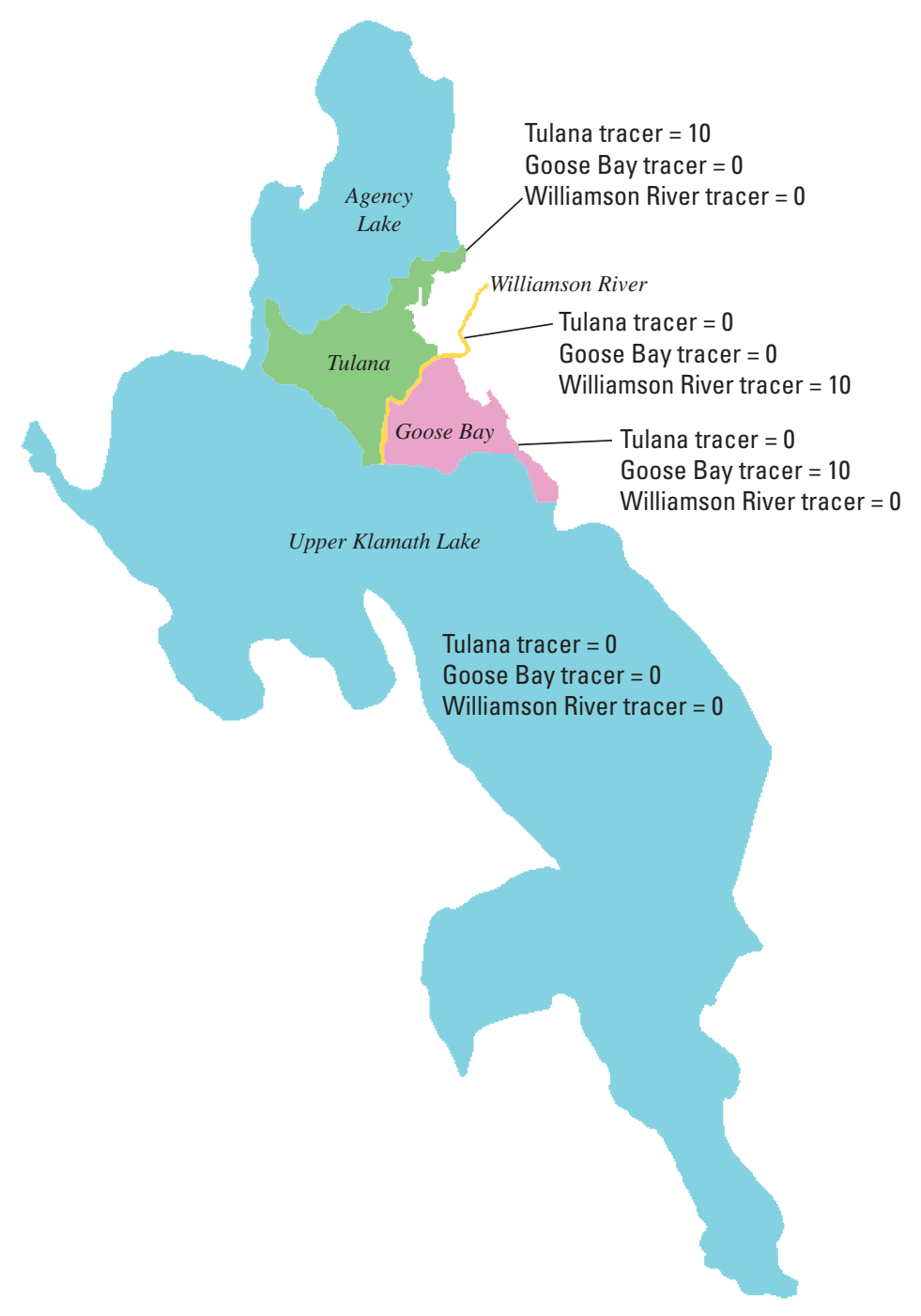

Figure 3. Initial values of tracers used in the tracer experiments within areas of Upper Klamath and Agency Lakes and the Williamson River Delta, Oregon. 
The change in mass of tracer represents an equivalent change in the volume of the water that started the simulation within the boundaries of either side of the Delta, and can be expressed as either a volume rate of change (cubic meters per day or per second) or as a fraction of the entire volume of either side of the Delta (fraction of Tulana or Goose Bay volume per day).

For example, the 1-day replacement rate in Tulana, in terms of cubic meters per day, was calculated as:

$$
\mathrm{RR}-\mathrm{TUL}=\left[1-\frac{\mathrm{M}-\mathrm{TUL}_{1}}{\mathrm{M}-\mathrm{TUL}}\right] \mathrm{V}-\mathrm{TUL}
$$

where $M-T U L_{0}$ and $M-T U L_{1}$ are the initial mass of the tracer within the boundaries of Tulana, and the mass of the tracer within the boundaries of Tulana at 1 day into the simulation, respectively. The volume of Tulana, V-TUL, is assumed invariant over the simulation.

Similarly, a 1-day partial replacement rate (RR-TULwWR or RR-GBWWR) for the third tracer representing Williamson River water was calculated at the end of the 1-day simulation as the increase in the total mass of the third tracer within Tulana and Goose Bay since the start of the simulation. This provided a means of tracking how much of the water that replaced water initially in either Tulana or Goose Bay came from the Williamson River. For example, the partial replacement rate between Williamson River water and Tulana, in terms of cubic meters per day, was calculated as:

$$
\text { RR-TULWWR }=\left[\frac{M-T U L W W R_{1}}{M-T U L_{0}}\right] V-T U L,
$$

where M-TULWWR ${ }_{1}$ is the mass of the Williamson River tracer within the boundaries of Tulana at the end of the 1-day simulation.

\section{Multivariate Regressions}

Multivariate regressions were developed for the total replacement rates in Tulana and Goose Bay, and for the partial replacement rates of water in Tulana and Goose Bay with water from the Williamson River. These regressions were based on the total and partial replacement rates calculated over 1 day as previously described and two different sets of independent variables in each case (variable definitions provided in table 2). Each set of independent variables incorporated lake elevation (elev), Williamson River inflow (flow), and a measure of wind strength (WRW-spd, -ew, or -ns) as recorded at the Williamson River West (WRW-MET) meteorological station (USGS site 422807121572500) within the Williamson River Delta (fig. 1). The first set of independent variables incorporated the wind as speed only:

$$
\begin{gathered}
R R-T U L=f(\text { elev, flow, } W R W-s p d), \\
R R-T U L w W R=f(\text { elev }, \text { flow, } W R W-s p d), \\
R R-G B=f(\text { elev, flow, } W R W-\text { spd }),
\end{gathered}
$$$$
R R-G B w W R=f(\text { elev, flow, } W R W-\text { spd }) .
$$

The second set of independent variables incorporated the wind as separate east-west and north-south components:

$$
\begin{gathered}
R R-T U L=f(\text { elev, flow, WRW-ew, } W R W-n s), \\
R R-T U L w W R=f(\text { elev, flow, } W R W-e w, W R W-n s), \\
R R-G B=f(\text { elev, flow, WRW-ew, } W R W-n s),
\end{gathered}
$$

$$
R R-G B w W R=f(\text { elev }, \text { flow, } W R W-e w, W R W-n s) .
$$

One value of each of the dependent variables was calculated for each tracer simulation, defined as starting at 5-day intervals between April 27 and September 29, 2008. The values of elev and flow were constants associated with each simulation. The value of wind speed or component magnitudes varied at the 10-minute observation interval over the simulation. These observations were condensed into a single explanatory variable for the multiple regression by taking the 75th percentile of the observations (subsampled at a 1-hour interval) of wind speed and the magnitude of the individual wind components. The use of the 75th percentile recognizes that peak winds may play a disproportionate role to their frequency of occurrence in accelerating the lake water. Each of the eight regressions were developed based on the calculations of total and partial replacement rates over 1 day (the first day of each simulation); the 75th percentile of the wind observations also was calculated for the first day of each simulation. 
The best functional form for each regression was determined by trial and error and by visual inspection of the residuals, as a function of the independent variables, as well as by using $R^{2}$ as a goodness-of-fit measure. The adjusted $R^{2}$ of the final regressions was the same as $R^{2}$ within two significant figures in all cases. The general form of regressions determined to be the "best" included the natural logarithm of lake elevation, wind speed and the magnitude of the east-west wind component as quadratic terms, and Williamson River inflow and the magnitude of the north-south wind component as linear terms. Multicollinearity of the independent variables was tested by examining the correlation matrix of the independent variables and assessing the values of variance inflation factors. All multivariate regression calculations were performed with $\mathrm{SAS}^{\circledR}$ version 9.1 (SAS Institute, Inc., 2004).

Following Wilks (1995), confidence intervals around the calculations of the dependent variable were estimated as the appropriate t-statistic (based on the number of degrees of freedom and the desired level of confidence) multiplied by the standard error of the estimate, which was computed as the square root of the mean squared residuals of the regression (RMSE). The RMSE values are reported with the results.

Table 2. Definitions of dependent and independent variables used in the regression models.

\begin{tabular}{|c|c|}
\hline Short name & Description \\
\hline RR-TUL & $\begin{array}{l}\text { Rate at which water in Tulana at time } \mathrm{t}=0 \text { is replaced by water from other parts of Agency or Upper Klamath Lakes, or the } \\
\text { Williamson River, in cubic meters per second. }\end{array}$ \\
\hline RR-TULWWR & $\begin{array}{l}\text { Rate at which water either in the Williamson River at time } t=0 \text {, or coming in from the Williamson River at any time in the } \\
\text { simulation, replaces water in Tulana at time } t=0 \text {, in cubic meters per second. }\end{array}$ \\
\hline RR-GBWWR & $\begin{array}{l}\text { Rate at which water either in the Williamson River at time } t=0 \text {, or coming in from the Williamson River at any time in the } \\
\text { simulation, replaces water in Goose Bay at time } t=0 \text {, in cubic meters per second. }\end{array}$ \\
\hline \multicolumn{2}{|r|}{ Independent variables } \\
\hline elev & Lake elevation, relative to an elevation of 4,135 feet, and converted to meters. \\
\hline WRW-ew & 75th percentile of the east-west component of wind at site WRW-MET in meters per second. \\
\hline WRW-ns & 75th percentile of the north-south component of wind at site WRW-MET in meters per second. \\
\hline
\end{tabular}




\section{Results of Tracer Experiments}

The wind observed at the Williamson River Delta was highly variable, in both speed and direction, between April 27 and September 29, 2008 (fig. 4). The 75th percentile of the east-west component was positive (indicating a westerly wind) on all dates, and generally ranged between about 1 and $6 \mathrm{~m} / \mathrm{s}$. The 75th percentile of the north-south component was positive and negative throughout the 5-month period and generally ranged between -3 and $4 \mathrm{~m} / \mathrm{s}$. The wind speed appears more visually correlated with the magnitude of the east-west wind component than with the north-south component, and this is confirmed with linear correlation analysis. The Pearson correlation coefficient $\mathrm{R}$ between the wind speed and the east-west component is 0.85 , and the correlation between the wind speed and the north-south component is statistically insignificant $(p<0.001)$.
The simulation of the Goose Bay tracer under strong northwest wind conditions as measured on May 22 (fig. 5A) shows that strong northwest winds push water in the southeast direction across Tulana and the Williamson River channel and then into Goose Bay. Water leaves Goose Bay through openings in levees on the south side and travels southward along the eastern shoreline with the prevailing clockwise circulation of Upper Klamath Lake. The simulation of the Williamson River tracer (fig. 5B) shows that most of the Williamson River flow is diverted through Goose Bay. The simulation of the Tulana tracer (fig. 5C) shows that northwest winds generate a complicated circulation pattern there. There is relatively less movement through the levee breaches on the south side of Tulana; primarily, water leaves through a breach just to the west of the mouth of the river channel. On the north side, water enters Tulana through the eastern breach and leaves through the western breach, creating an exchange with water from Agency Lake.

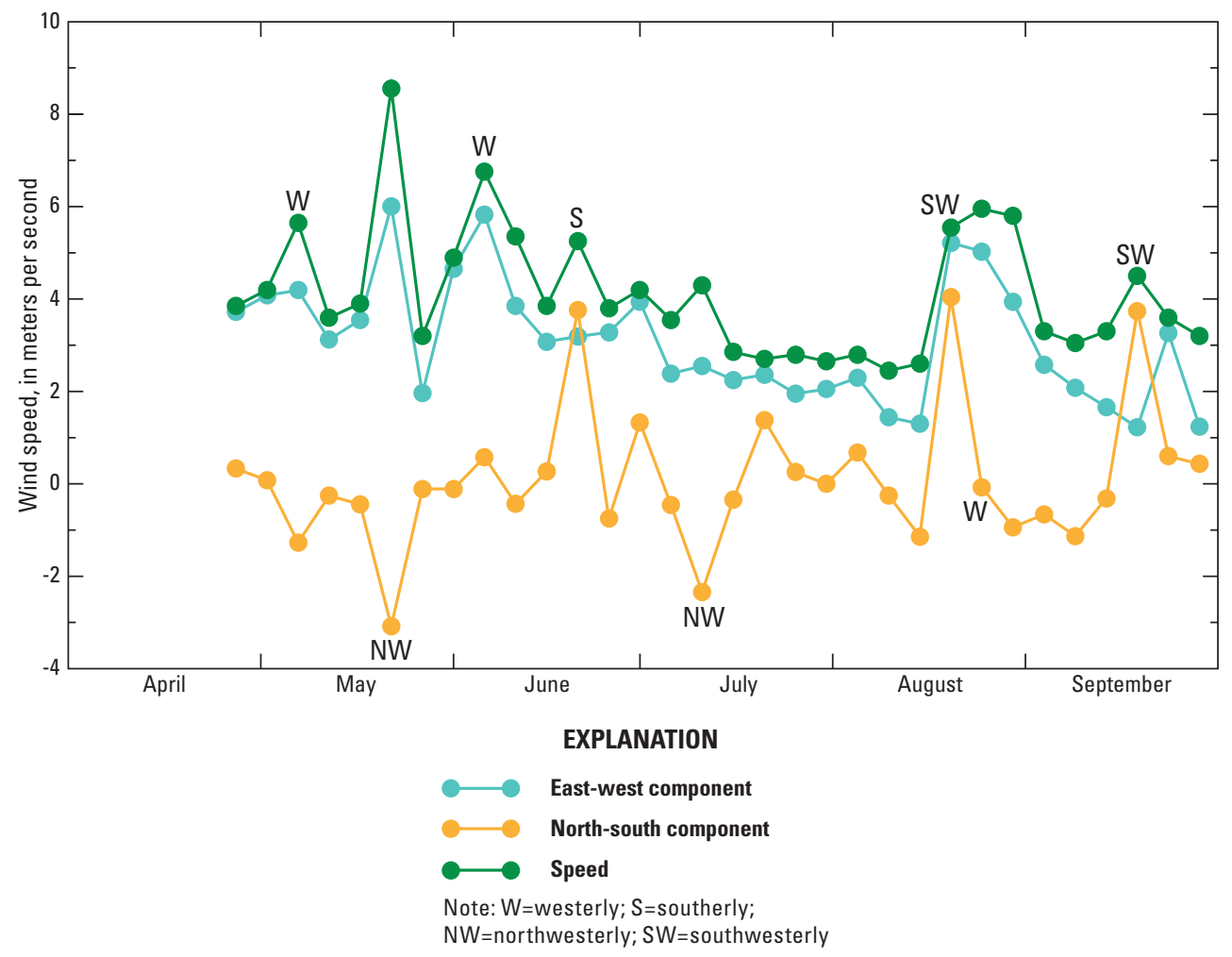

Figure 4. Time series of the 75th percentile wind observations at meteorological site Williamson River West (WRW-MET), Upper Klamath Lake, Oregon, at 5-day intervals between April 27 and September 29, 2008. 
$\boldsymbol{A}$

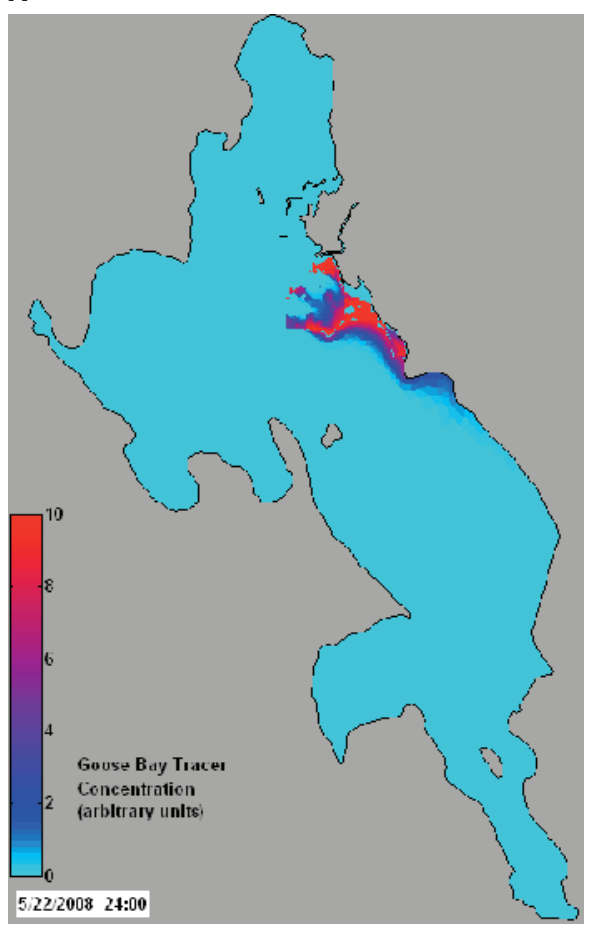

B

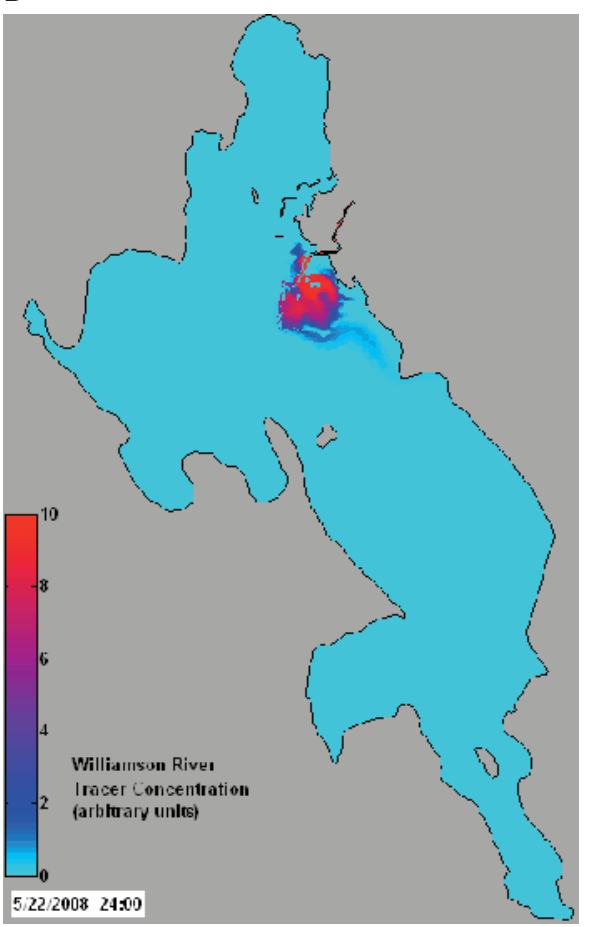

$c$

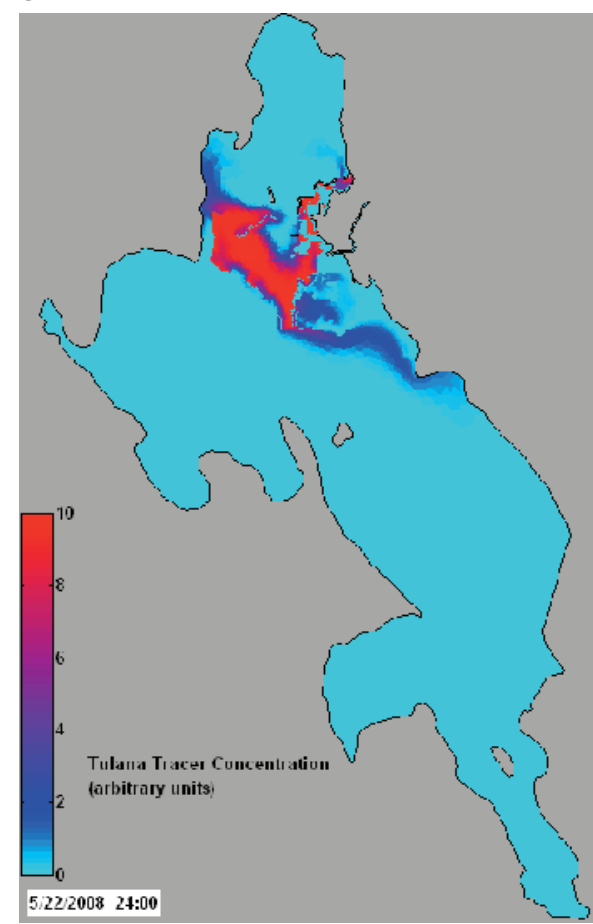

Figure 5. The last frame from an animation of the simulation of the $(A)$ Goose Bay, $(B)$ Williamson River, and $(C)$ Tulana tracer under strong northwest wind conditions as measured on May 22, 2008, at Upper Klamath Lake, Oregon, starting at 1:00 AM and ending at 12:00 PM. The lake elevation was set to 4,141.5 feet and flow from the Williamson River to 25 cubic meters per second. Click on the image to view the animation.

\section{Dependence of Flow through the Delta on Wind}

The replacement rate in both Tulana and Goose Bay was highly variable between April and September when lake elevation and Williamson River inflow were held constant (fig. 6). When expressed as a fraction of the entire Goose Bay volume replaced in a single day, the total replacement rate in Goose Bay (with water from all sources) varied nearly 5 -fold between the lowest value of 0.11 volume per day on September 19 and the higest value of 0.50 volume per day on May 22. This variability is attributable to the considerable changes in wind over the time period. Furthermore, the total replacement rate was moderately correlated with the $75^{\text {th }}$ percentile of wind speed $(R=0.71, p<0.001)$, and several peaks in the total replacement rate coincided with peaks in the wind speed (May 7 and 22, June 6, and August 25); however, there were notable exceptions. In particular, total replacement rate minima occurred coincident with wind speed maxima on June 21, August 20, and September 19, and each of these dates was characterized by positive peaks in the north-south wind component (fig. 4), indicating southerly or southwesterly winds. 
Most of the water that left Goose Bay was replaced by water from the Williamson River, for the entire range of wind conditions (fig. 6). In contrast, water in Tulana was replaced largely by water from Agency and Upper Klamath Lakes, and less water as a fraction of the total came from the Williamson River (fig. 6). When expressed as a fraction of the entire Tulana volume replaced in a single day, the total replacement rate in Tulana varied nearly 3 -fold between the lowest value of 0.08 volume per day on July 31 and the highest value of 0.30 volume per day on May 22. The replacement rate was correlated with the 75th percentile of wind speed $(R=0.83$, $\mathrm{p}<0.001)$. In contrast to Goose Bay, the total replacement rate in Tulana on June 21, August 20, and September 19, dates that were characterized by positive peaks in the north-south wind component, was either a small maximum or not an extreme value. The strong northwesterly winds on May 22 resulted in a peak in the total replacement rate of Tulana water, but almost none of that water was replaced with water from the Williamson River (fig. 6).

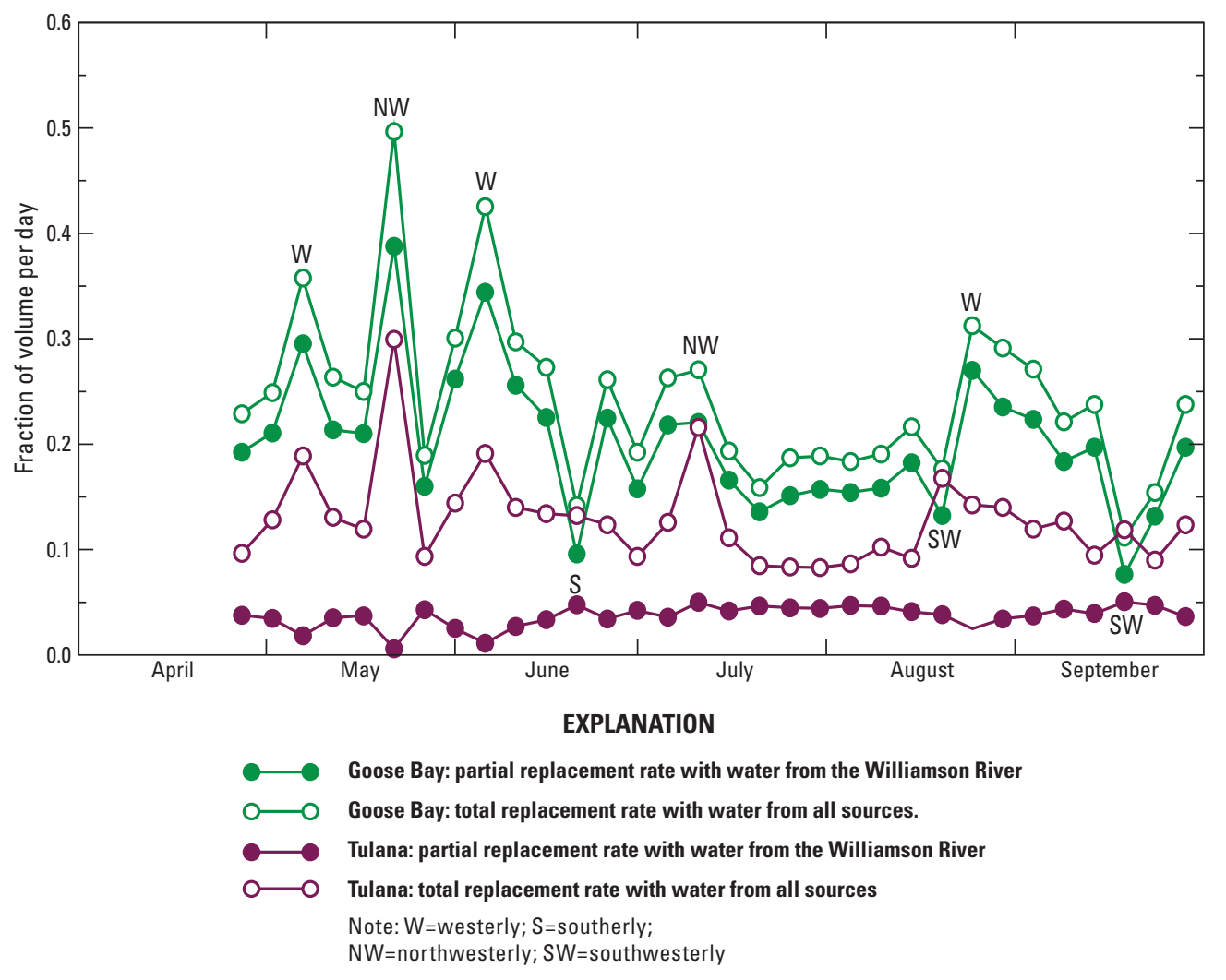

Figure 6. The total fraction of Goose Bay and Tulana water replaced in 1 day, and the partial fraction of Goose Bay and Tulana water replaced with water from the Williamson River in 1 day, Upper Klamath Lake, Oregon, based on numerical tracer experiments. The calculations were made over the first day of consecutive 5-day periods between April 27 and September 29, 2008. The lake elevation was set to 4,141.5 feet and flow from the Williamson River was set to 25 cubic meters per second. 
The reciprocal of the volume replacement rates provides a theoretical replacement time for the replacement of all of the water in Goose Bay and Tulana (fig. 7). This calculation is not an estimate of the true water replacement time in Goose Bay or Tulana, because it is based on the conditions during only 1 day. It is not likely that replacement would occur at the same daily rate until the entire volume is replaced because conditions - wind conditions in particularwould not realistically remain constant over several days. Nonetheless, this theoretical replacement time provides another interpretation of the volume replacement rates (fig. 6), and the relative differences in theoretical replacement time between Goose Bay and Tulana are instructive. When expressed in this way, it is clear that water in Goose Bay has a shorter replacement time than water in Tulana, largely owing to the smaller volume in Goose Bay. At a lake elevation of 4,141.5 ft, for example, the volumes of Goose Bay and Tulana are approximately $5.3 \times 10^{6} \mathrm{~m}^{3}$ and $2.4 \times 10^{7} \mathrm{~m}^{3}$, respectively. The replacement time for water in Goose Bay varied from a minimum of 2.0 days during strong northwesterly wind conditions on May 22 to a maximum of 9.0 days during southwesterly wind conditions on September 19. The replacement time for Tulana water varied from a minimum of 3.3 days on May 22 to a maximum of 12.1 days during the relatively weak mid-summer winds on July 31. Under certain conditions, however, the replacement time for Tulana can approach or even be less than that in Goose Bay, as occurred on June 21, August 20, and September 19, all days characterized by a strong southerly wind component. In figure 7 it also is apparent that strong winds in April and May resulted in the shortest replacement times, whereas the weakest winds in July and August resulted in the longest replacement times.

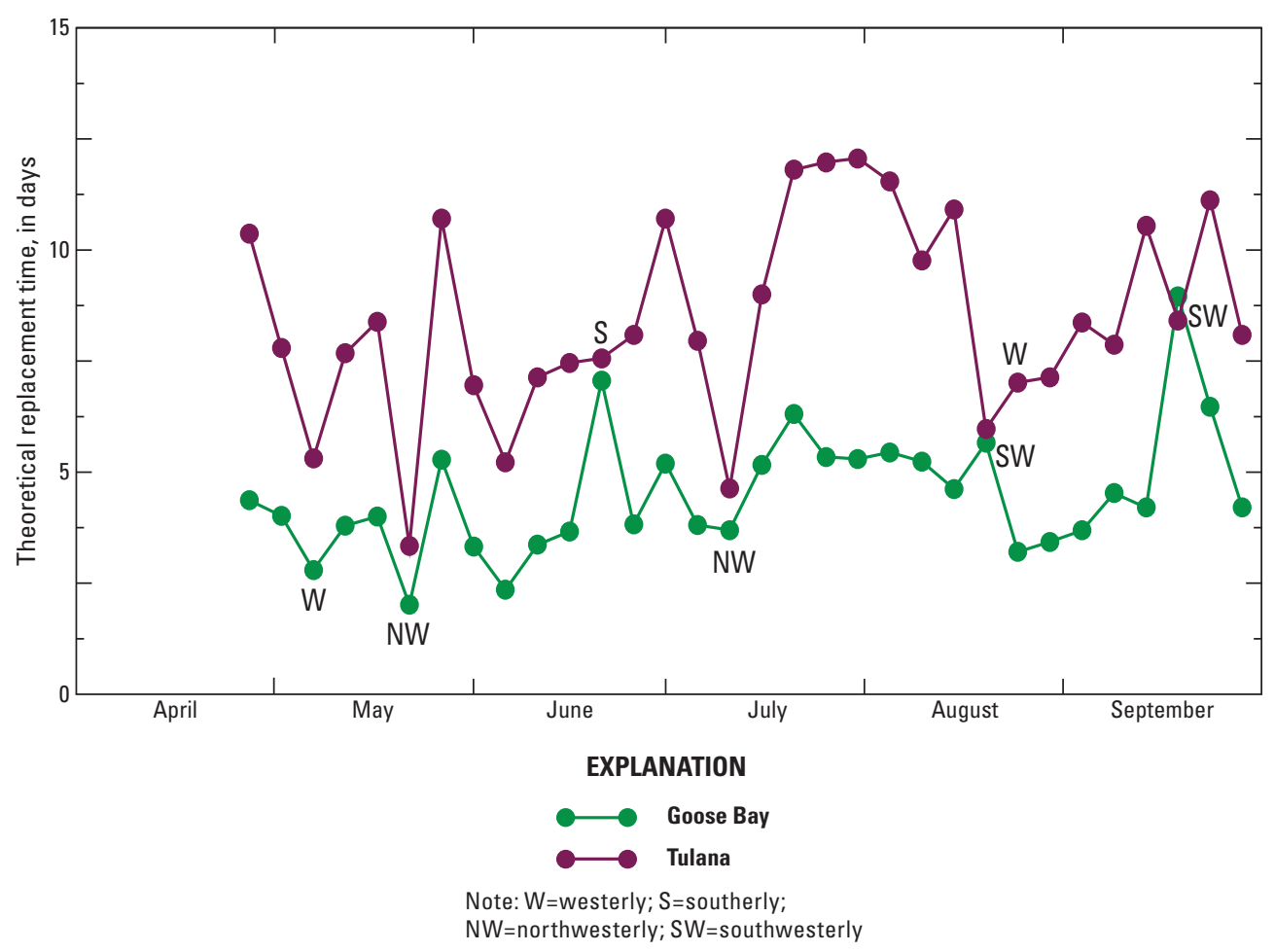

Figure 7. Theoretical water replacement time for Goose Bay and Tulana in Upper Klamath Lake, Oregon, based on numerical tracer experiments. Calculations were made at 5-day intervals between April 27 and September 29, 2008. The lake elevation was set to 4,141.5 feet and flow from the Williamson River to was set 25 cubic meters per second. 


\section{Dependence of Flow through the Delta on Inflow and Elevation}

To examine the flow of water through the Delta as a function of Williamson River inflow and lake elevation, the volume fraction of water replaced per day was converted to a volume rate per second, in order to provide a convenient means of putting the movement of water through the Delta into perspective for comparison to the Williamson River inflow. The replacement rate of water in both Goose Bay and Tulana had a strong dependence on inflow from the Williamson River, such that replacement rates were higher at higher inflows (fig. 8). That dependence tended to be diminished at higher wind speeds, particularly in the case of winds with a strong northerly component. During the strong northwesterly winds on May 22, the Goose Bay replacement rate varied from 33.1 to $38.2 \mathrm{~m}^{3} / \mathrm{s}$, whereas during the low winds on July 31 the Goose Bay replacement rate varied from 9.1 to $31.7 \mathrm{~m}^{3} / \mathrm{s}$. In Tulana, the replacement rate varied from 82.0 to $96.3 \mathrm{~m}^{3} / \mathrm{s}$ on May 22 and from 18.8 to $59.0 \mathrm{~m}^{3} / \mathrm{s}$ on July 31 . The replacement rate also had a strong dependence on lake elevation (fig. 9), but the dependence tended to increase at higher wind speeds. Goose Bay replacement rate varied from 6.8 to $50.4 \mathrm{~m}^{3} / \mathrm{s}$ on May 22 and from 4.4 to $14.8 \mathrm{~m}^{3} / \mathrm{s}$ on July 31; Tulana replacement rates varied from 53.8 to $113 \mathrm{~m}^{3} / \mathrm{s}$ on May 22 and from 13.5 to $29.6 \mathrm{~m}^{3} / \mathrm{s}$ on July 31. In Goose Bay, the replacement rate of water appeared to meet a lower threshold of $4-5 \mathrm{~m}^{3} / \mathrm{s}$ that was relatively insensitive to wind speed at a lake elevation between 4,141.5 and 4,140.5 ft.

The partial replacement rate of water in Goose Bay or Tulana with Williamson River water depended on Williamson River inflow, such that it increased at higher inflows (ig. 10). At the lowest flows, the exchange between the Williamson River and Tulana was cut off on May 22, during strong northwest winds. The partial replacement rate of water in Goose Bay or Tulana also increased at higher lake elevation (fig. 11). The dependence of the partial replacement rate in both sides of the Delta on lake elevation was subject to a threshold between elevations of 4,140.5 and 4,141.5 ft. Below this threshold, the partial replacement rate was not strongly influenced by wind, but rather was controlled primarily by the levee openings around the river channel (fig. 11) and, based on the results in figure 10, on the Williamson River inflow.

Wood River inflows were calculated as 0.3 times the flow in the Williamson River. This ratio of the Wood River flow to the Williamson River flow is, however, highly variable, both within a single year and in a given month between years, and the value of 0.3 is at the low end of the observed values. For this reason, sensitivity to this ratio was investigated. An additional model simulation was done with boundary conditions at the Wood River defined as 0.6 times the flow in the Williamson River; for this model simulation lake elevation was set to 4,141.5 ft and the Williamson River flow was set to $25 \mathrm{~m}^{3} / \mathrm{s}$. Doubling the flow in the Wood River relative to the Williamson River had a small effect (median values differed by less than 2 percent) on the replacement rate in Tulana, and an even smaller effect on the replacement rate in Goose Bay (median values differed by less than 1 percent). The minimum, median, and maximum Tulana replacement rates when the ratio of Wood to Williamson flows was set to 0.3 was 22.6, 33.8 , and $80.3 \mathrm{~m}^{3} / \mathrm{s}$, whereas the same statistics were 23.6 , 34.4 , and $79.7 \mathrm{~m}^{3} / \mathrm{s}$ when the ratio of Wood to Williamson flows was set to 0.6 . The minimum, median, and maximum Goose Bay replacement rates when the ratio of Wood to Williamson flows was set to 0.3 was $7.01,14.5$, and $29.2 \mathrm{~m}^{3} / \mathrm{s}$, whereas the same statistics were $7.08,14.6$, and $29.3 \mathrm{~m}^{3} / \mathrm{s}$ when the ratio of Wood to Williamson flows was set to 0.6. 

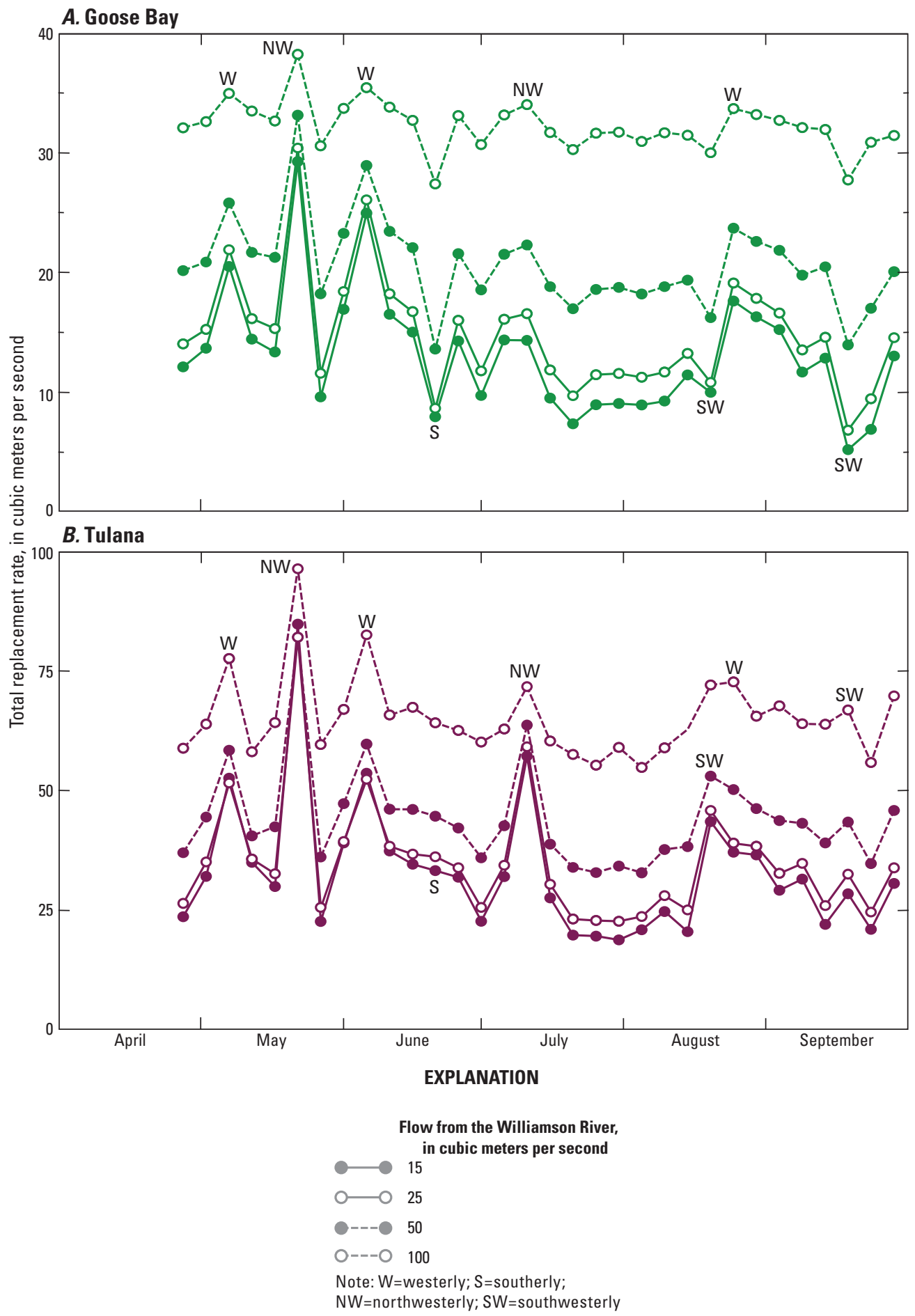

Figure 8. Replacement rate of water calculated over 1 day in $(A)$ Goose Bay and $(B)$ Tulana, Upper Klamath Lake, Oregon, based on numerical tracer experiments. The calculations were made at 5-day intervals between April 27 and October 9, 2008. The lake elevation was set to $4,141.5$ feet and flow from the Williamson River was varied between 15 and 100 cubic meters per second. 

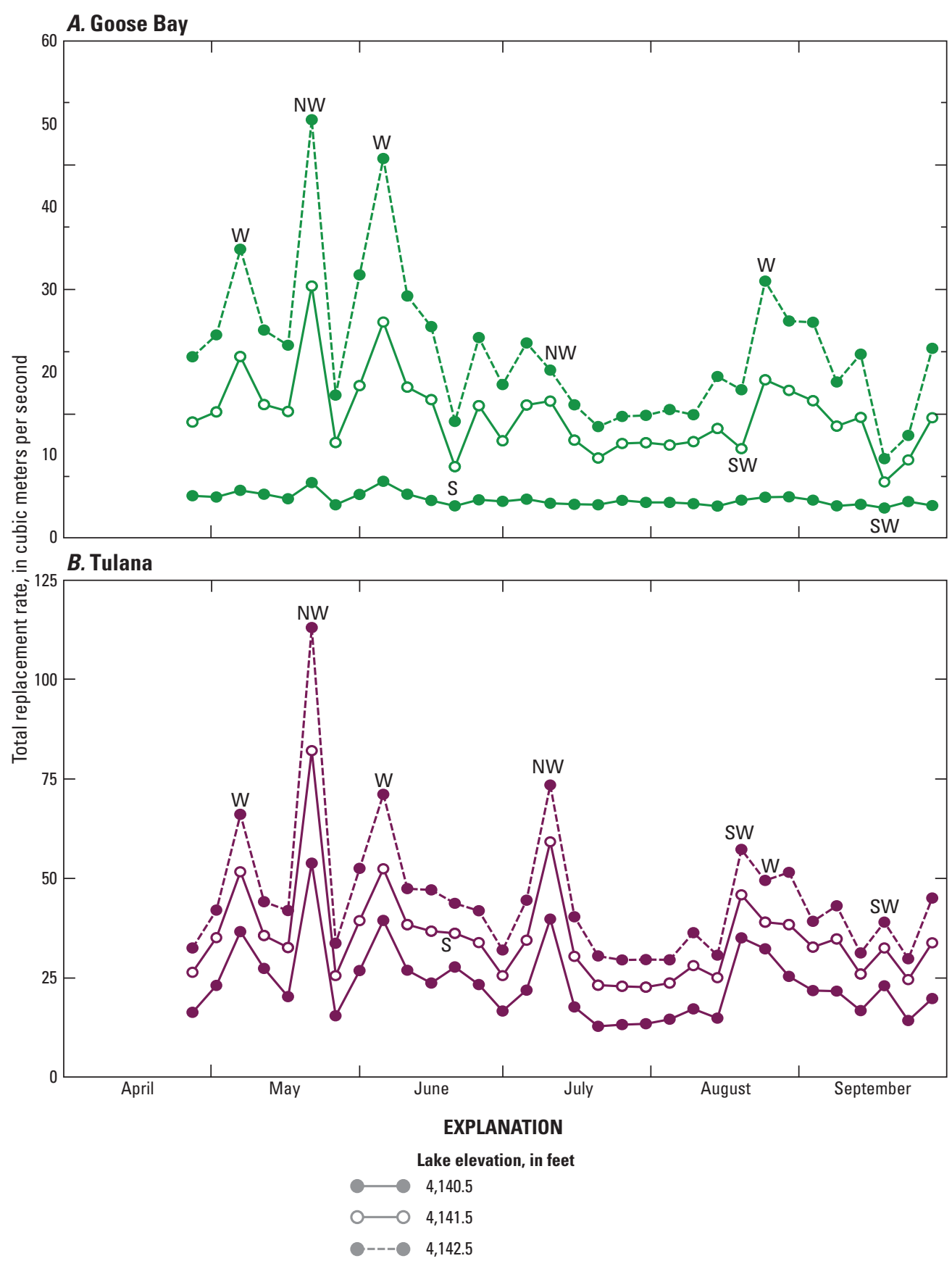

Note: $W=$ westerly; $S=$ southerly;

$\mathrm{NW}=$ northwesterly; $S W=$ southwesterly

Figure 9. Replacement rate of water calculated over 1 day in $(A)$ Goose Bay and $(B)$ Tulana, Upper Klamath Lake, Oregon, based on numerical tracer experiments. The calculations were made at 5-day intervals between April 27 and 0ctober 9, 2008. The flow from the Williamson River was set to 25 cubic meters per second and the lake elevation was varied between $4,140.5$ and $4,142.5$ feet. 


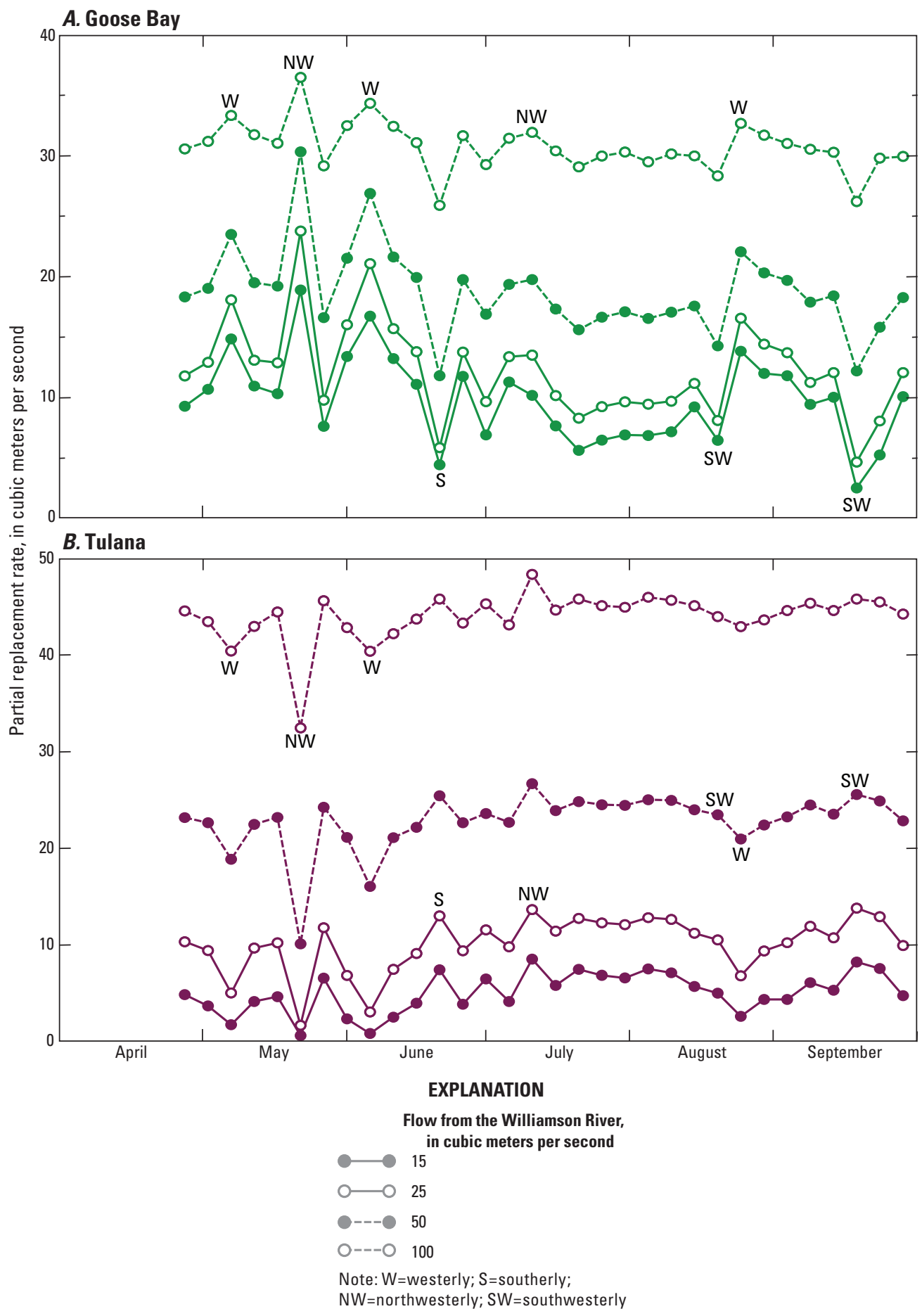

Figure 10. One-day partial replacement rate of water in $(A)$ Goose Bay and $(B)$ Tulana with Williamson River water, Upper Klamath Lake, Oregon, based on numerical tracer experiments. The calculations were made at 5-day intervals between April 27 and 0 ctober 9, 2008. The lake elevation was set to 4,141.5 feet and flow from the Williamson River was varied between 15 and 100 cubic meters per second. 

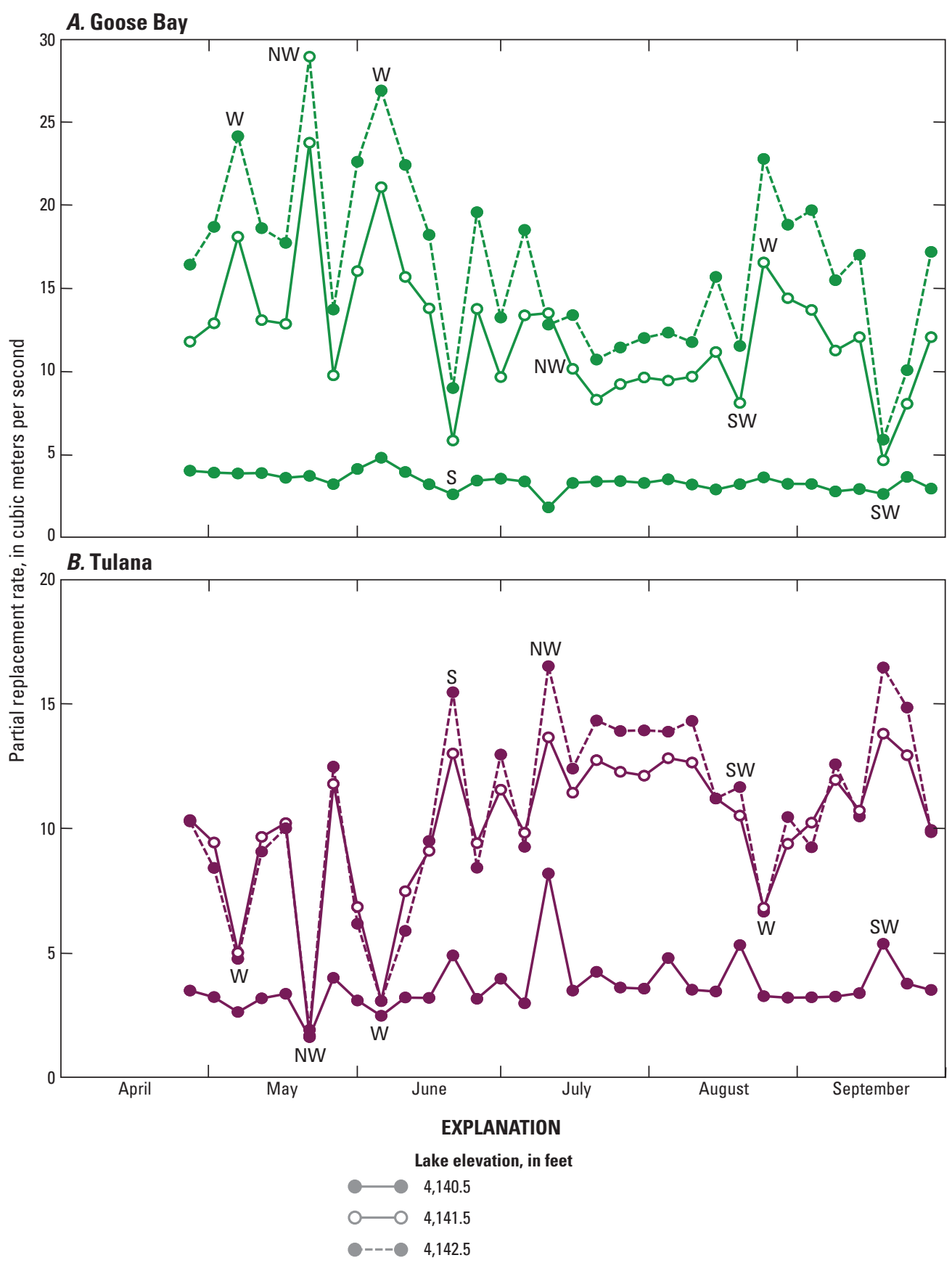

Note: $\mathrm{W}=$ westerly; $\mathrm{S}=$ southerly; $\mathrm{NW}=$ northwesterly; $\mathrm{SW}=$ southwesterly

Figure 11. One-day partial replacement rate of water in $(A)$ Goose Bay and $(B)$ Tulana with Williamson River water, Upper Klamath Lake, Oregon, based on numerical tracer experiments. The calculations were made at 5-day intervals between April 27 and October 9, 2008. The flow from the Williamson River was set to 25 cubic meters per second and the lake elevation was varied between 4,140.5 and 4,142.5 feet. 


\section{Results of Multivariate Regression}

The results of the multivariate regression modeling showed that the three variables-lake elevation, Williamson River inflow, and wind speed-were sufficient to explain most of the variability in the computed total and partial replacement rates (table 3 , fig. 12). The amount of variability explained by the best regression for each variable, as measured by the coefficient of determination $R^{2}$, ranged from 87 percent for RR-TUL to 97 percent for RR-TULWWR, and all regressions were significant $(p<0.0001)$. The inclusion of east-west and north-south wind components rather than wind speed alone as independent variables improved the fit of the regression for three out of four dependent variables (table 3). Thus, the incorporation of wind direction generally resulted in a better model for the replacement rates-the improvement in fit as measured by $R^{2}$ ranged from 3.4 percent for RR-GB to 7.8 percent for RR-TULwWR. The $R^{2}$ values associated with the regression models based on wind speed alone, however, were all 0.87 or greater (table 3 ); therefore, depending on the question being addressed, the greater simplicity of the windspeed-only models may outweigh the benefit of the better fit obtained by using the models that incorporate wind direction.

Most regressions were based on 384 tracer experiments, derived from $(32$ wind values $) \times(4$ Williamson River inflow values) $\times$ (3 lake elevation values). The regressions for partial replacement rates in both sides of the Delta (RR-GBwWR and RR-TULwWR) that incorporated the magnitude of wind components as independent variables have a lower $\mathrm{N}$ and a higher valid minimum lake elevation than all the other regressions, because the tracer experiments at the lowest lake elevation were not used in developing those regressions. A satisfactory regression model for those dependent variables, based on using wind components as independent variables (determined by an $R^{2}>0.80$ ), could not be developed without removing the tracer experiments at the lowest elevation, a consequence of the fact that exchange between the Williamson River and Goose Bay or Tulana becomes severely constrained and relatively insensitive to wind direction at an unknown elevation between 4,140.5 and 4,141.5 ft (fig. 11). Satisfactory regressions using wind speed as an independent variable could be developed for RR-GBWWR and RR-TULwWR when all three lake elevations were included.

The regression models quantify the dependencies of replacement rates on wind, Williamson River inflow, and lake elevation shown in figures 8-11, and interpolate those relations continuously across the parameter space. When the wind-speed only regression models are presented as contour plots in two-dimensional parameter space, the increase of both RR-GB and RR-TUL with lake elevation, Williamson River inflow, and wind speed (figs. 13 and 14A, B) is clear. RR-TUL has a stronger dependence on wind speed than does RR-GB. It is also apparent that both RR-GBWWR and RR-TULWWR increase with lake elevation and Williamson River inflow, but RR-GBWWR increases with wind speed, whereas RR-TULwWR decreases with wind speed (figs. 13 and $\underline{14 C}$ and $\underline{D}$ ). Thus, an increase in the strength of the wind forcing at the water surface creates a tradeoff between the two sides of the Delta, such that more Williamson River water flows into the Goose Bay side at higher wind speeds. To illustrate the dependence on wind direction, the regression models that use wind components as independent variables to explain RR-GBwWR and RR-TULWWR are plotted in the parameter space defined by the east-west and north-south wind component (fig. 15). The partial replacement in Goose Bay, RR-GBwWR, increases with the westerly and the northerly components of the wind, whereas the partial replacement in Tulana, RR-TULwWR, has the opposite dependence. Thus, winds with both a northerly and westerly component, which are the prevailing winds during the spring and summer months, result in more movement of Williamson River water into the Goose Bay side of the Delta than into the Tulana side. 
Table 3. Summary of the best regression models for dependent variables.

[Regression models are only valid for positive values of the dependent variable. Abbreviations: $\mathrm{R}^{2}$, coefficient of determination of the regression; $\mathrm{N}$, number of points on which the regression is based; RMSE, square root of mean of squared residuals; $\mathrm{m}, \mathrm{meter} ; \mathrm{m}^{3} / \mathrm{s}$, cubic meter per second; $\mathrm{m} / \mathrm{s}$, meter per second]

\begin{tabular}{|c|c|c|c|c|c|c|c|}
\hline $\begin{array}{l}\text { Dependent } \\
\text { variable }\end{array}$ & Coefficient & $\begin{array}{l}\text { Standard error } \\
\text { of coefficient }\end{array}$ & $\begin{array}{l}\text { Independent } \\
\text { variable term }\end{array}$ & $\mathbf{N}$ & RMSE & $R^{2}$ & $\begin{array}{c}\text { Approximate } \\
\text { range of validity } \\
\text { in independent } \\
\text { variable }\end{array}$ \\
\hline RR-TUL & $\begin{array}{r}-42.44473865 \\
81.87242342 \\
0.35964436 \\
0.69270801\end{array}$ & $\begin{array}{l}2.08449253 \\
2.84703177 \\
0.01097397 \\
0.02603299\end{array}$ & $\begin{array}{l}\text { Intercept } \\
\text { In(elev) } \\
\text { flow } \\
\text { WRW-spd }\end{array}$ & 384 & 7.07 & 0.87 & $\begin{array}{l}1.68 \text { to } 2.29 \mathrm{~m} \\
15 \text { to } 100 \mathrm{~m}^{3} / \mathrm{s} \\
2 \text { to } 8 \mathrm{~m} / \mathrm{s}\end{array}$ \\
\hline RR-TUL & $\begin{array}{r}-38.90516911 \\
81.87242342 \\
0.35964436 \\
0.86273339 \\
-1.91547011\end{array}$ & $\begin{array}{l}2.46103413 \\
3.37633539 \\
0.01301418 \\
0.04709037 \\
0.28692868\end{array}$ & $\begin{array}{l}\text { Intercept } \\
\text { In(elev) } \\
\text { flow } \\
\text { WRW-ew² } \\
\text { WRW-ns }\end{array}$ & 384 & 8.39 & 0.82 & $\begin{array}{l}1.68 \text { to } 2.29 \mathrm{~m} \\
15 \text { to } 100 \mathrm{~m}^{3} / \mathrm{s} \\
0 \text { to } 6 \mathrm{~m} / \mathrm{s} \\
-3 \text { to } 4 \mathrm{~m} / \mathrm{s}\end{array}$ \\
\hline RR-TULWWR & $\begin{array}{r}-30.49463191 \\
45.42855411 \\
0.43293842 \\
-0.13604931\end{array}$ & $\begin{array}{l}1.53175031 \\
2.09208800 \\
0.00806401 \\
0.01912986\end{array}$ & $\begin{array}{l}\text { Intercept } \\
\text { In(elev) } \\
\text { flow } \\
\text { WRW-spd }\end{array}$ & 384 & 5.20 & 0.90 & $\begin{array}{l}1.68 \text { to } 2.29 \mathrm{~m} \\
15 \text { to } 100 \mathrm{~m}^{3} / \mathrm{s} \\
2 \text { to } 8 \mathrm{~m} / \mathrm{s}\end{array}$ \\
\hline RR-TULwWR & $\begin{array}{r}-18.45596673 \\
25.28231919 \\
0.51888396 \\
-0.27756614 \\
0.89053414\end{array}$ & $\begin{array}{l}2.11183519 \\
2.73959633 \\
0.00596123 \\
0.02157004 \\
0.13142948\end{array}$ & $\begin{array}{l}\text { Intercept } \\
\text { In(elev) } \\
\text { flow } \\
\text { WRW-ew² } \\
\text { WRW-ns }\end{array}$ & 256 & 3.14 & 0.97 & $\begin{array}{l}1.98 \text { to } 2.29 \mathrm{~m} \\
15 \text { to } 100 \mathrm{~m}^{3} / \mathrm{s} \\
0 \text { to } 6 \mathrm{~m} / \mathrm{s} \\
-3 \text { to } 4 \mathrm{~m} / \mathrm{s}\end{array}$ \\
\hline RR-GB & $\begin{array}{r}-35.07833716 \\
59.19746357 \\
0.21526783 \\
0.21664750\end{array}$ & $\begin{array}{l}1.22514180 \\
1.67331740 \\
0.00644985 \\
0.01530066\end{array}$ & $\begin{array}{l}\text { Intercept } \\
\text { In(elev) } \\
\text { flow } \\
\text { WRW-spd }\end{array}$ & 384 & 4.16 & 0.87 & $\begin{array}{l}1.68 \text { to } 2.29 \mathrm{~m} \\
15 \text { to } 100 \mathrm{~m}^{3} / \mathrm{s} \\
2 \text { to } 8 \mathrm{~m} / \mathrm{s}\end{array}$ \\
\hline RR-GB & $\begin{array}{r}-34.46172443 \\
59.19746357 \\
0.21526783 \\
0.31945875 \\
-1.26920650\end{array}$ & $\begin{array}{l}1.08404760 \\
1.48722369 \\
0.00573255 \\
0.02074258 \\
0.12638766\end{array}$ & $\begin{array}{l}\text { Intercept } \\
\text { In(elev) } \\
\text { flow } \\
\text { WRW-ew² } \\
\text { WRW-ns }\end{array}$ & 384 & 3.69 & 0.90 & $\begin{array}{l}1.68 \text { to } 2.29 \mathrm{~m} \\
15 \text { to } 100 \mathrm{~m}^{3} / \mathrm{s} \\
0 \text { to } 6 \mathrm{~m} / \mathrm{s} \\
-3 \text { to } 4 \mathrm{~m} / \mathrm{s}\end{array}$ \\
\hline RR-GBWWR & $\begin{array}{r}-29.54220553 \\
47.06878709 \\
0.24375799 \\
0.13413116\end{array}$ & $\begin{array}{l}1.00020449 \\
1.36609459 \\
0.00526565 \\
0.01249144\end{array}$ & $\begin{array}{c}\text { Intercept } \\
\text { In(elev) } \\
\text { flow } \\
\text { WRW-spd }\end{array}$ & 384 & 3.39 & 0.90 & $\begin{array}{l}1.68 \text { to } 2.29 \mathrm{~m} \\
15 \text { to } 100 \mathrm{~m}^{3} / \mathrm{s} \\
2 \text { to } 8 \mathrm{~m} / \mathrm{s}\end{array}$ \\
\hline RR-GBWWR & $\begin{array}{r}-21.36380879 \\
34.10486667 \\
0.26859670 \\
0.30166437 \\
-1.56144917\end{array}$ & $\begin{array}{l}1.56763112 \\
2.03362293 \\
0.00442506 \\
0.01601160 \\
0.09756109\end{array}$ & $\begin{array}{l}\text { Intercept } \\
\text { In(elev) } \\
\text { flow } \\
\text { WRW-ew² } \\
\text { WRW-ns }\end{array}$ & 256 & 2.33 & 0.95 & $\begin{array}{l}1.98 \text { to } 2.29 \mathrm{~m} \\
15 \text { to } 100 \mathrm{~m}^{3} / \mathrm{s} \\
0 \text { to } 6 \mathrm{~m} / \mathrm{s} \\
-3 \text { to } 4 \mathrm{~m} / \mathrm{s}\end{array}$ \\
\hline
\end{tabular}


A. RR-TUL
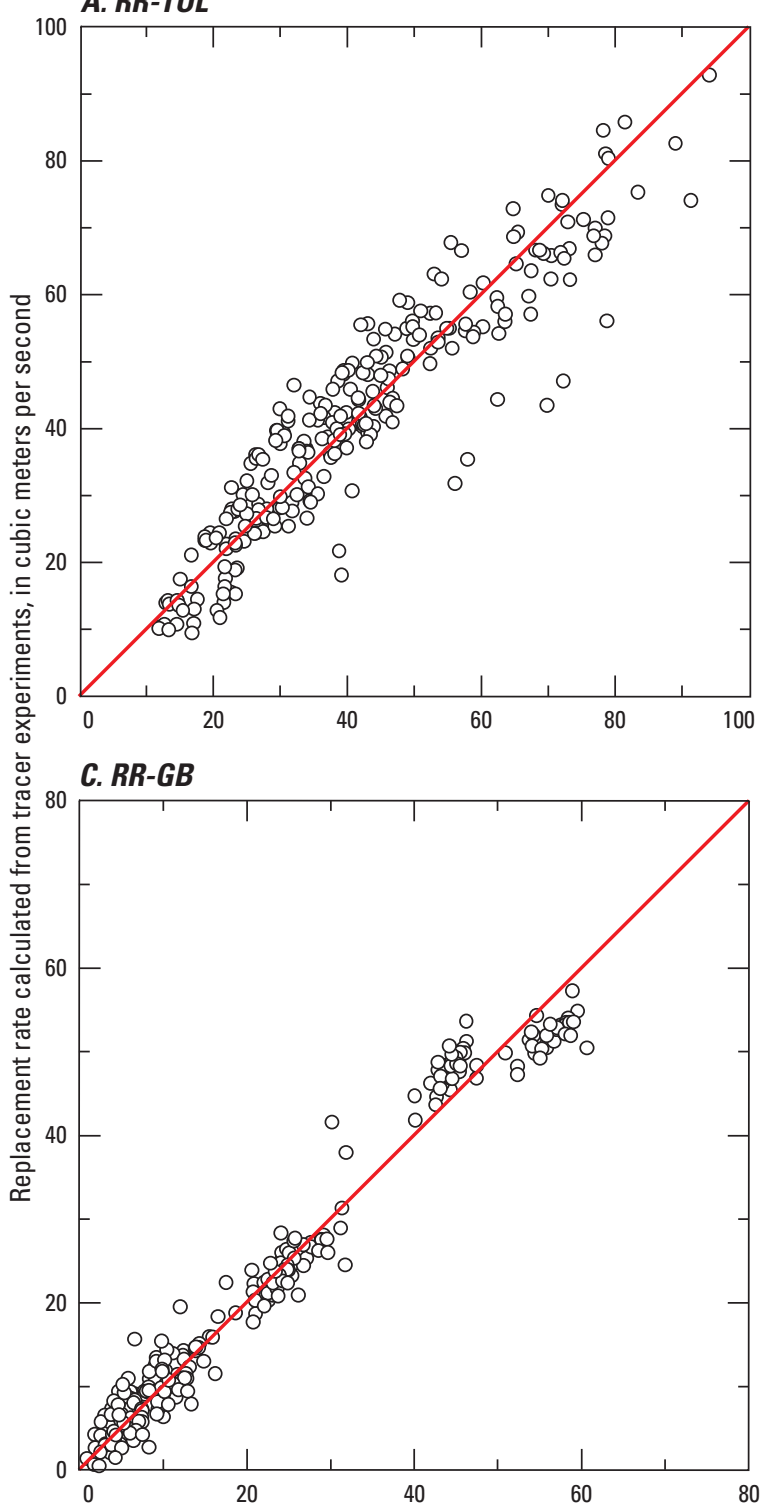

B. RR-TULWWR

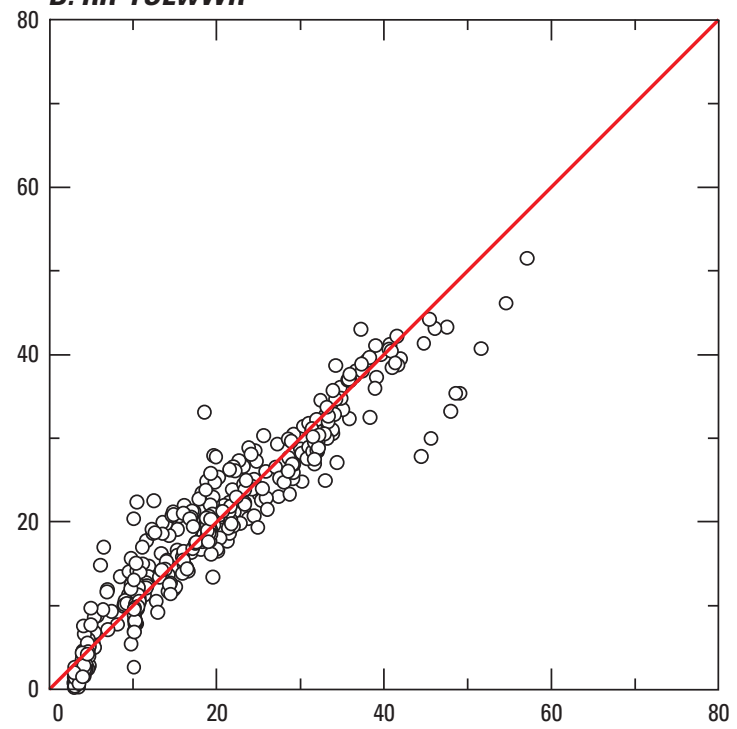

D. RR-GBWWR

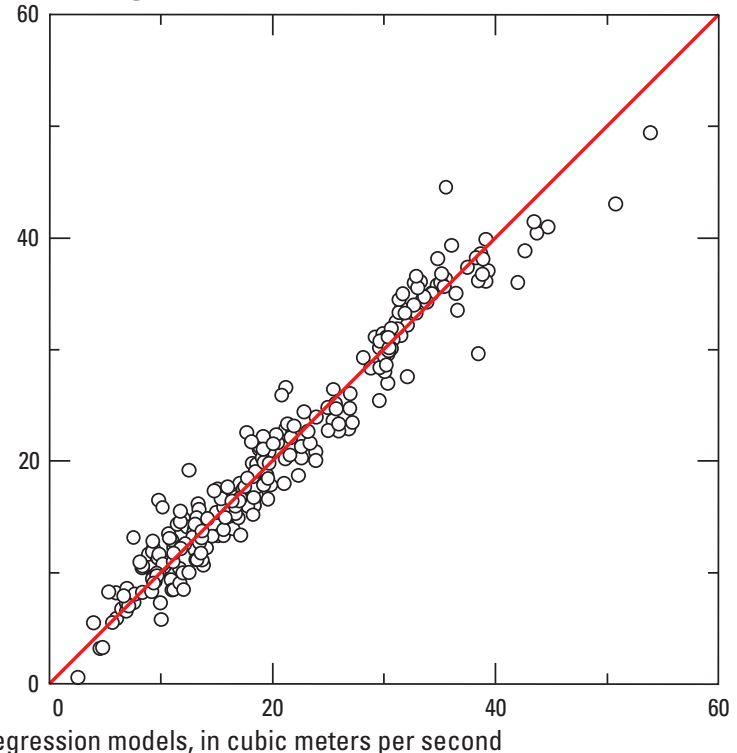

Figure 12. Best regressions for each dependent variable, where the dependent variables were based on numerical tracer experiments and calculations made at 5-day intervals between April 27 and October 9, 2008. The dependent variables are $(A) R R-T U L,(B) R R-T U L W W R,(C) R R-G B$, and $(D) R R-G B W W R$. The independent variables in each case are wind, lake elevation, and Williamson River inflow. 


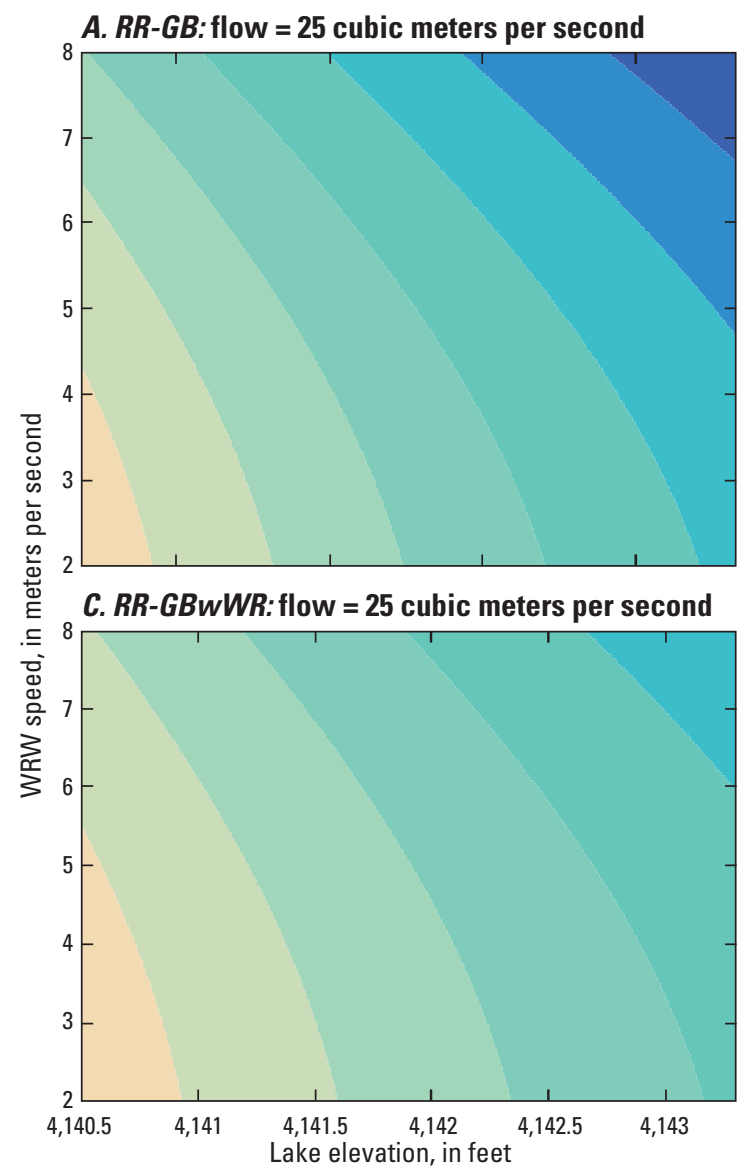

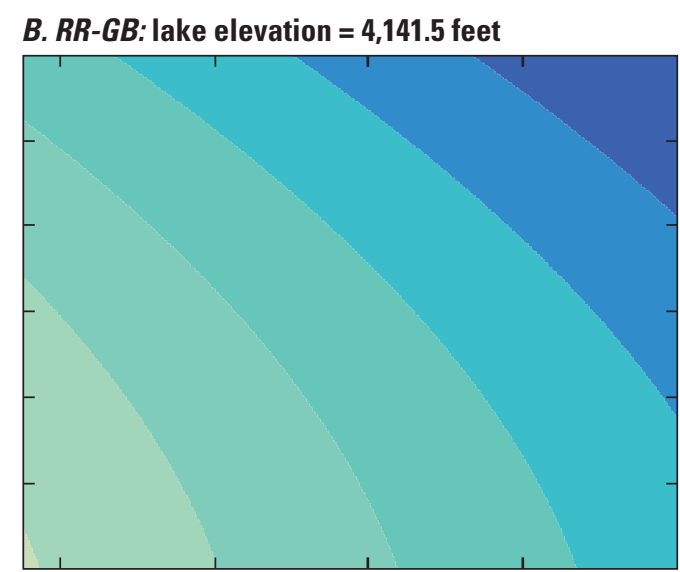

D. $R R-G B w W R$ : lake elevation $=4,141.5$ feet

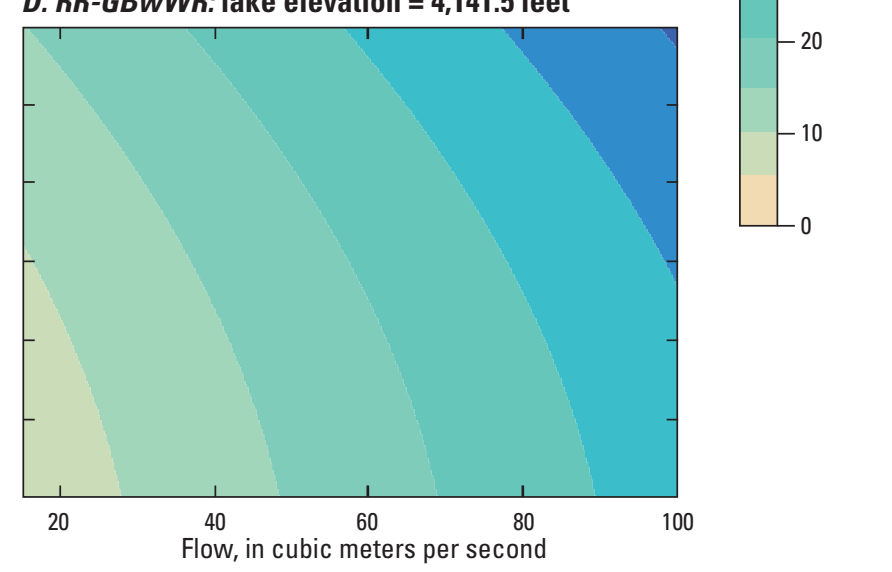

\section{EXPLANATION}

Replacement rate, in cubic meters per second

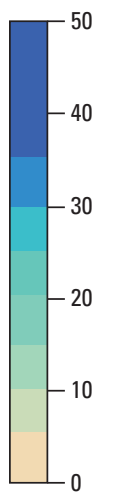

Figure 13. Best regressions for Goose Bay total replacement rate $(R R-G B)$ and partial replacement rate $(R R-G B w W R)$, Upper Klamath Lake, Oregon, as a function of values of the independent variables lake elevation and Williamson River inflow. Elevations are in feet above Bureau of Reclamation datum. 


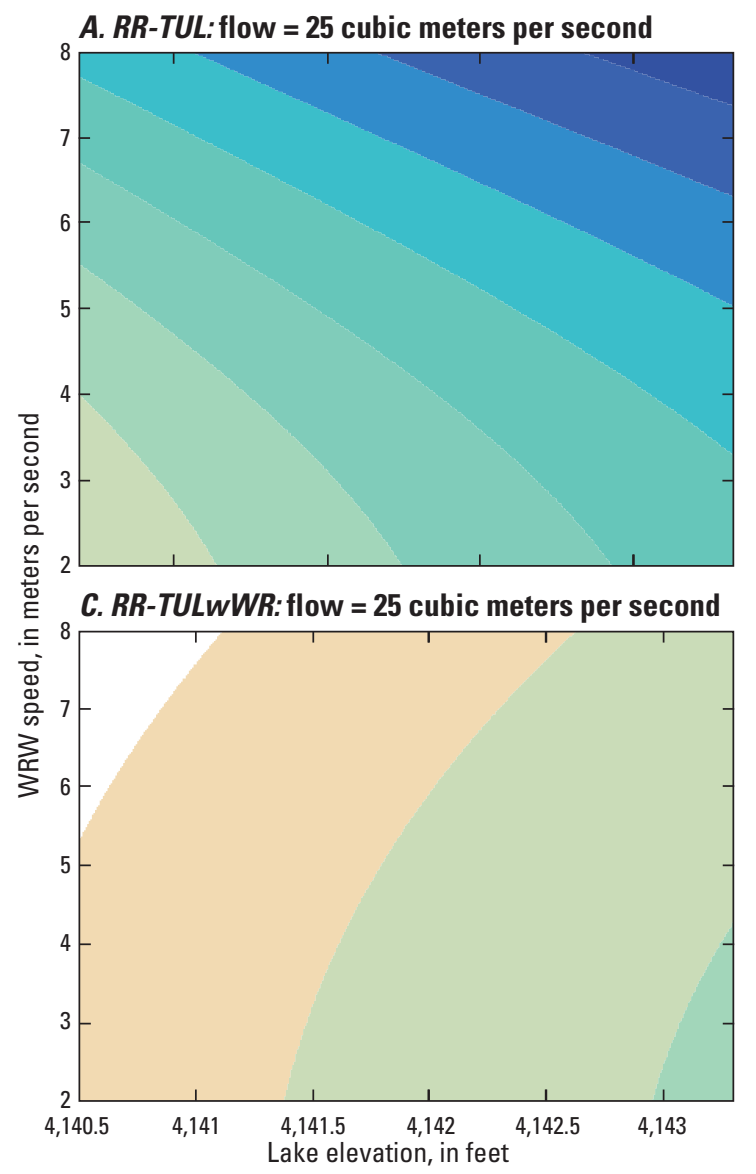

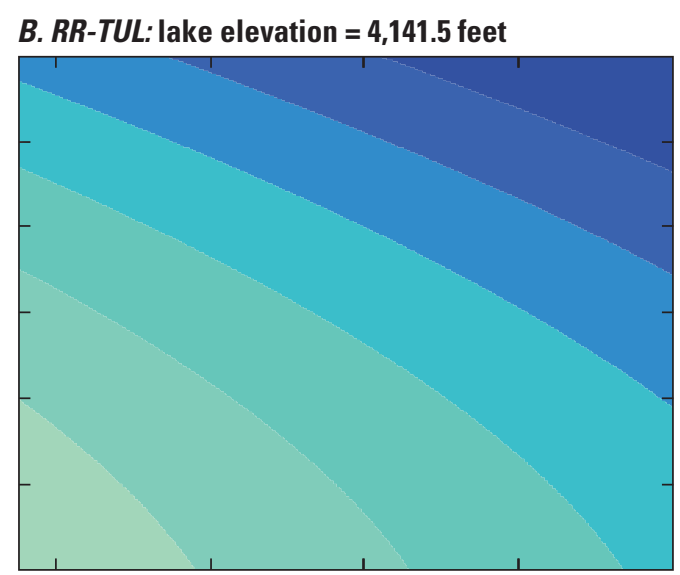

D. $R$ R-TULwWR: lake elevation $=4,141.5$ feet

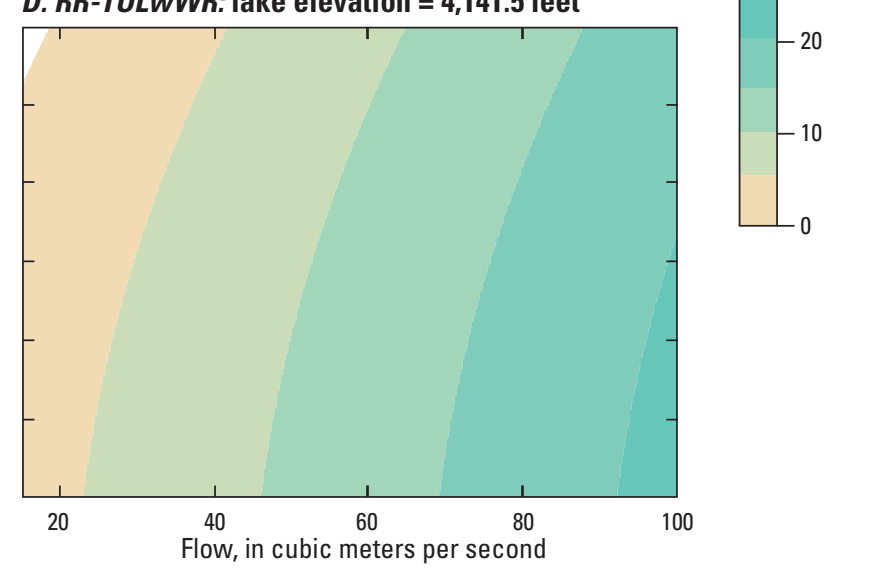

Figure 14. Best regressions for Tulana replacement rate (RR-TUL) and partial replacement rate $(R R-T U L W W R)$, Upper Klamath Lake, Oregon, as a function of values of the independent variables lake elevation and Williamson River inflow. Elevations are in feet above Bureau of Reclamation datum. 


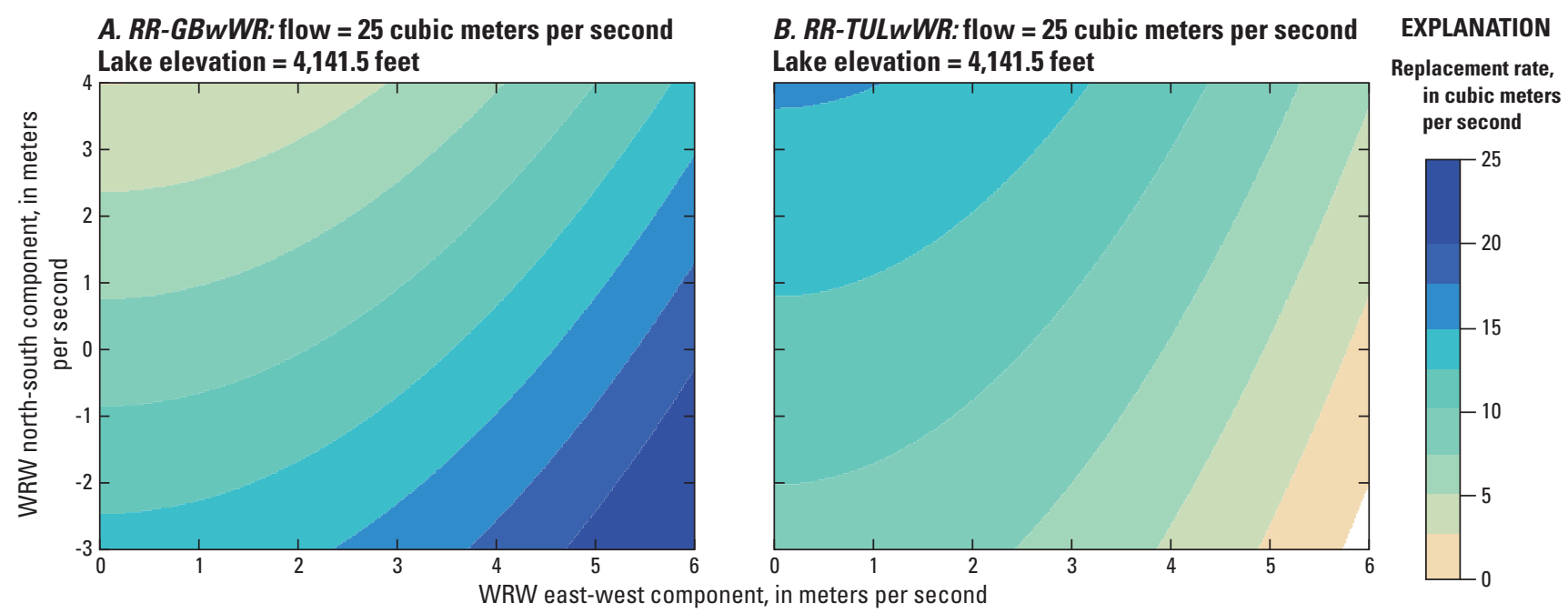

Figure 15. Best regressions for the partial replacement rate in Goose Bay (RR-GBWWR), and Tulana (RR-TULwWR), Upper Klamath Lake, Oregon, as a function of values of the independent variables magnitude of the east-west and north-south wind component at the Williamson River West meteorological station. Increasing positive values of the east-west component indicate increasing westerly winds; increasing positive values of the north-south component indicate increasing southerly winds. Elevations are in feet above Bureau of Reclamation datum.

\section{Use of Regression Models}

To demonstrate their use as a tool for estimating the rate at which water moves through the Delta, the regression models were used to calculate total and partial replacement rates at two different flow and wind conditions that are roughly representative of spring and summer conditions (figs. 16 and 17). Spring conditions were represented by a Williamson River inflow of $60 \mathrm{~m}^{3} / \mathrm{s}$ and strong northwesterly winds as measured on May 22, 2008. Summer conditions were represented by a Williamson River inflow of $13 \mathrm{~m}^{3} / \mathrm{s}$ and weak winds as measured on August 10, 2008. The average May lake elevation for the period of record from water year 1975 to 2010 (station 1150700, U.S. Geological Survey, 2011) ranged from $4,141.2$ to $4,143.2 \mathrm{ft}$. Over that range, the total replacement rate of Tulana water under typical spring conditions could be expected to range from 82 to $105 \mathrm{~m}^{3} / \mathrm{s}$, and the partial replacement rate of Tulana water with Williamson River water from 14 to $27 \mathrm{~m}^{3} / \mathrm{s}$ (ig. 16). Thus, between approximately 17 and 26 percent of the water that passes through Tulana comes from the Williamson River, the rest coming from Upper Klamath and Agency Lakes through (and over, at the highest elevations) the levees on the north and south side of Tulana. Similarly, the total replacement rate of Goose Bay water ranges from 32 to $48 \mathrm{~m}^{3} / \mathrm{s}$, and the partial replacement rate of Goose Bay water with Williamson River water ranges from 25 to $38 \mathrm{~m}^{3} / \mathrm{s}$, meaning that approximately 78 percent of the water that passes through Goose Bay comes from the Williamson River under typical spring conditions, the rest coming from Upper Klamath Lake over the levees on the south side of Goose Bay, and also from Tulana across the Williamson River channel. Of the water that leaves the Williamson River channel before it enters Upper Klamath Lake, between 64 percent (at a lake elevation of 4,141.2 ft) and 58 percent (at a lake elevation of 4,143.2 ft) can be expected to flow through the Goose Bay side of the Delta under conditions representative of spring. 

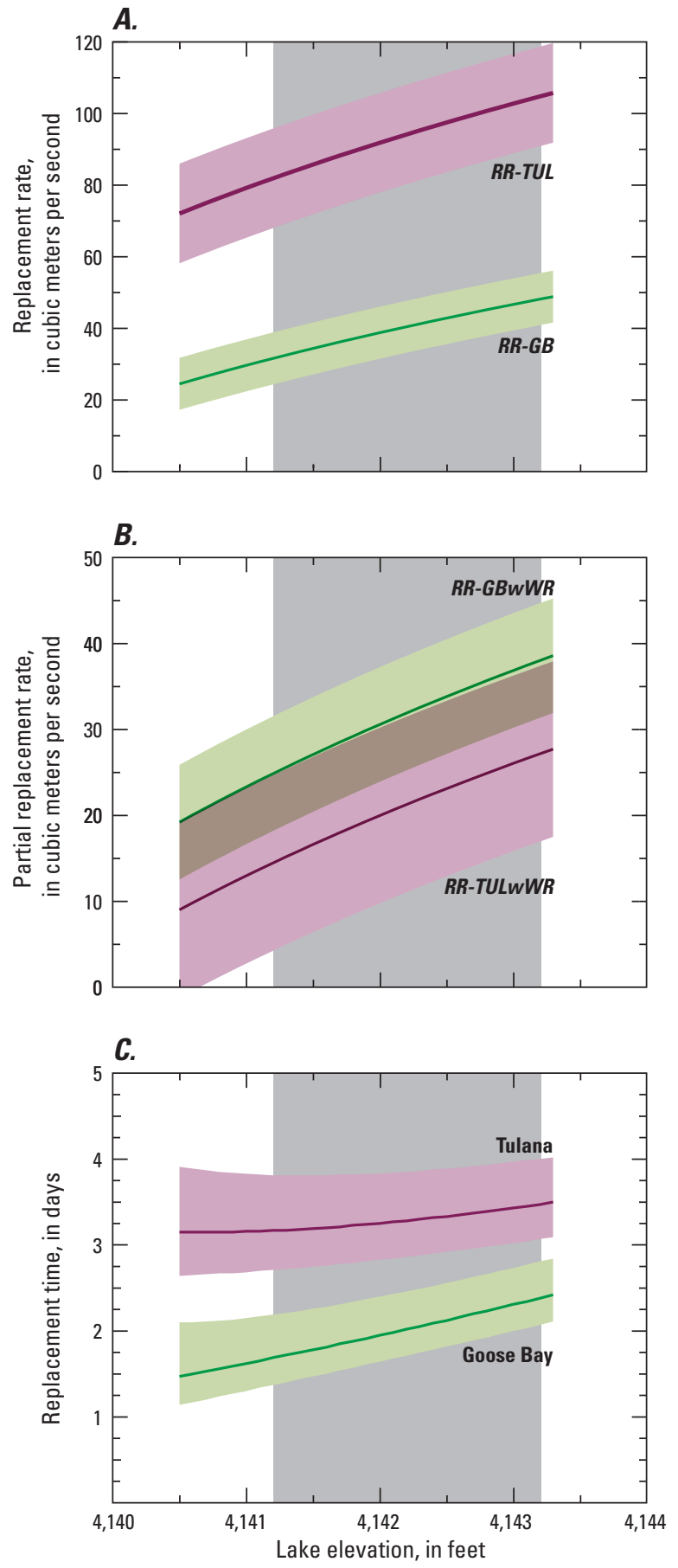

EXPLANATION

Tulana-regression line and shaded 95-percent confidence interval

Area of overlap of shaded confidence intervals

Goose Bay-regression line and shaded 95-percent confidence interval

Average May lake elevation
Figure 16. (A) Total rate of replacement in Goose Bay and Tulana in Upper Klamath Lake, Oregon, $(B)$ partial replacement rate of water in Goose Bay and Tulana with Williamson River water, and $(C)$ theoretical replacement time of the water in Goose Bay and Tulana, as a function of lake elevation, as calculated with multi-variate regression models. To obtain results shown, wind conditions were set to strong northwesterly winds as observed on May 22, 2008, and the Williamson River inflow was set to 60 cubic meters per second. Elevations are in feet above Bureau of Reclamation datum. 

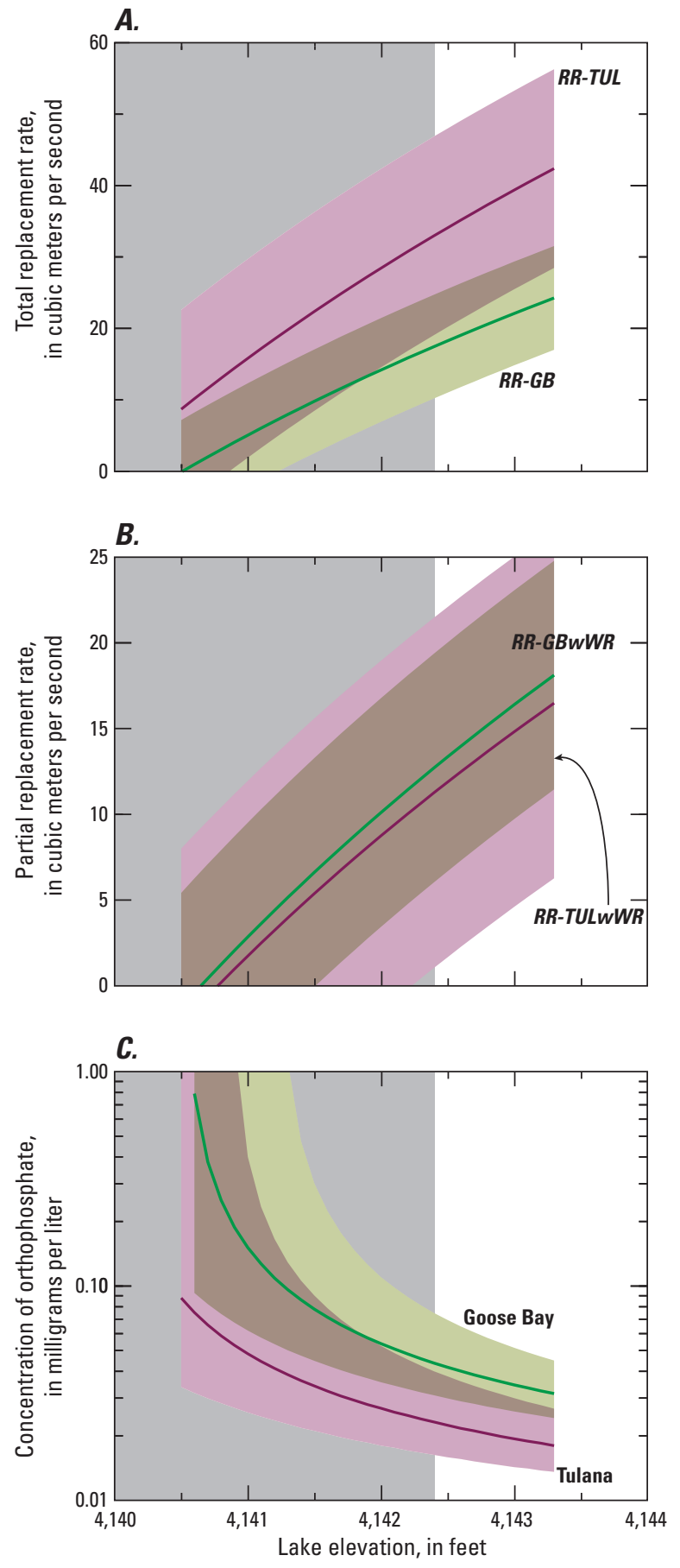

EXPLANATION

Tulana-regression line and shaded 95-percent confidence interval

Area of overlap of shaded confidence intervals

Goose Bay-regression line and shaded 95-percent confidence interval

Average August lake elevation
Figure 17. (A) Total rate of replacement in Goose Bay and Tulana in Upper Klamath Lake, Oregon, $(B)$ partial replacement rate of water in Goose Bay and Tulana with Williamson River water, and $(C)$ estimated contribution of benthic fluxes to orthophosphate concentration in Goose Bay and Tulana as a function of lake elevation, as calculated with multivariate regression models. To obtain results shown, wind conditions were set to weak late-summer winds as observed on August 10, 2008, and the Williamson River inflow was set to 13 cubic meters per second. To obtain orthophosphate concentration, the benthic load was set to 66 kilograms per day. Elevations are in feet above Bureau of Reclamation datum. 
During spring, when larval suckers drift down the Williamson River, it is of interest to understand whether they are transported completely passively, where they are likely to go, and how long they are likely to spend on either side of the Delta. Because of the inverse relation between volume replacement rate and the theoretical replacement time (figs. 6 and 7), the time it takes for a parcel of water from the Williamson River to pass through Goose Bay is likely to be much less than it takes for a parcel of water from the Williamson River to pass through Tulana; the theoretical replacement time in Goose Bay under typical spring conditions ranges from 1.7 to 2.2 days between a lake elevation of 4,141.2 and 4,143.2 ft (fig. 16C).

During summer, management questions are more likely to concern water quality. For some period of time, the restored lands of the Delta can be expected to be a source of nutrients to the water column. As vegetation matures, that relation may reverse and the wetlands might remove nutrients from the water column. In either case, the rate at which water flows over the landscape, in combination with the magnitude of the nutrient fluxes to or from Delta soils, determines the concentration of nutrients in the water as it leaves the Delta and enters Upper Klamath Lake. A first-order approximation to the concentration of a nutrient of interest that would be added to water flowing over the Delta could be obtained by making the simplifying assumption that either side of the Delta acts as a continuously stirred tank reactor, in which case the steady-state contribution of the Delta soils to the water-column concentration would be K/RR, where $\mathrm{RR}$ is the total replacement rate, and $\mathrm{K}$ is the rate at which the mass of nutrient is added, summed over the entire surface area involved. For example, Kuwabara and others (2010) measured summer benthic fluxes of orthophosphate from Tulana soils in July 2009, and estimated the load to the water column at $66 \mathrm{~kg} / \mathrm{d}$. At that rate, and under the assumed summer conditions, the steady-state contribution of Delta soils to the concentration of orthophosphate in the waters of Tulana is estimated to range from $0.088 \mathrm{mg} / \mathrm{L}$ at an elevation of $4,140.5 \mathrm{ft}$ to $0.023 \mathrm{mg} / \mathrm{L}$ at an elevation of $4,142.4 \mathrm{ft}$, the upper end of the range in average August lake elevation for the period of record (fig. 17C). The calculated concentration of orthophosphate is higher in Goose Bay than Tulana because the total replacement rate is lower (fig. 17A), and ranges from $0.79 \mathrm{mg} / \mathrm{L}$ at an elevation of $4,140.6 \mathrm{ft}$ to $0.044 \mathrm{mg} / \mathrm{L}$ at an elevation of 4,142.4 ft. The regression equations provide estimates of concentration at lower lake elevations, but those estimates become imprecise at the low replacement rates associated with the lowest lake elevations (fig. 17C), indicating that the range of validity of the regression model is more limited than shown in table 3 under the assumed conditions. Additionally, the regressions for partial replacement in Goose Bay and Tulana produce negative values below a lake elevation of about 4,140.8 ft, further showing that the range of validity in the regression models can be more limited than shown in table 3 under some combinations of assumed conditions.

The limitations of this work are substantial, and because the regressions cannot be validated with observations, the accuracy cannot be definitively assessed; the results should be interpreted accordingly. First, the regressions are based on 1-day simulations of numerical tracers. The 1-day timeframe provided a good correspondence between the results, as measured by total or partial replacement of water in the Delta, and the observed winds, which, while having generalized seasonal characteristics of being stronger in the spring and autumn and weaker in the summer, vary from day to day. Therefore, calculating replacement over a longer time frame integrates the results of consecutive days when conditions might have been quite different. Extrapolating these results beyond a day is difficult, and could only be done in a probabilistic sense by using a distribution of wind characteristics. Although this is possible, at some point the advantage of using a simple estimation technique is lost and it is wiser to move to using a spatially explicit model to get a more accurate result. Second, the range of validity, particularly in lake elevation, is limited and more exploration could be done to determine at what lake elevation the exchange with Goose Bay becomes severely curtailed, which occurs between an elevation of 4,140.5 and 4,141.5 ft. Third, the range of wind conditions considered was limited to winds with a westerly component. While these are the most common winds over Upper Klamath Lake, winds do occasionally reverse and come from the south to southeast. These winds are likely to move water from the Williamson River preferentially into Tulana instead of Goose Bay, and the regression equations have not been tested and would likely fail under these conditions. Finally, as the Delta vegetation matures, one can expect significant changes in how water moves through the Delta, based on the depth of water and the type of vegetation that thrives in that depth.

Nonetheless, the results presented here are useful in that they provide insight into how movement of water through the Delta responds to hydrology as defined by the lake elevation and Williamson River inflow, and to wind forcing conditions at the lake surface. The regression equations provide a quick and easy-to-use means of making rough estimates of how fast water moves through both sides of the Delta and how the water entering the Delta at the Williamson River might be partitioned between Goose Bay and Tulana under varying conditions. These estimates can inform management decisions aimed at restoring fisheries, as they influence the extent to which the Delta areas are utilized by fish larvae in the spring. As demonstrated, the regression equations can also be used to estimate the steady-state water column concentrations that would result for assumed, uniform flux rates of water quality constituents in the Delta. 


\section{Summary}

The hydrodynamic model of Upper Klamath and Agency Lakes, Oregon, was used to run numerical tracer experiments in order to understand the relative effects of wind, lake elevation, and Williamson River inflow on flow and transport (the movement of water and passively transported constituents) through the Williamson River Delta (hereafter referred to as the Delta). This was accomplished by running 384 realizations of the numerical experiment while systematically varying only 1 of the 3 (wind speed, lake elevation, and Williamson River inflow, if wind speed is used) or 4 (east-west wind component, north-south wind component, lake elevation, and Williamson River inflow, if wind speed and direction are used) independent variables at a time. The results of the tracer experiments were quantified and compared by calculating the amount of water on either side of the Delta that left the boundaries of the Delta and was replaced by water from any other part of Upper Klamath or Agency Lakes or the Williamson River in 1 day (the total replacement rate), and the amount of Williamson River water that replaced water on either side of the Delta in 1 day (the partial replacement rate). These calculated total and partial replacement rates were used to develop quantitative relations between transport through the restored areas of the Delta and lake elevation, Williamson River inflow, and wind speed and direction. The quantitative relations took the form of multivariate regression models. The dependent variables of these models were the calculated total and partial replacement rates in the northwest (Tulana) or southeast (Goose Bay) side of the Delta. The independent variables included (1) Williamson River inflow, (2) Upper Klamath Lake elevation, and (3) either wind speed or the magnitude of separate east-west and north-south wind components.

The results of the tracer experiments and regression models showed that the replacement rate of water increased in Tulana and Goose Bay with increasing lake elevation, Williamson River inflow, and wind speed, although the replacement rate in Tulana had a stronger dependence on wind speed than did the replacement rate in Goose Bay. The fraction of Williamson River inflow passing through either side of the Delta (the partial replacement rate) increased with lake elevation and Williamson River inflow. The dependence of the partial replacement rate on wind speed was different for the two sides of the Delta, such that the partial replacement rate of water in Goose Bay with Williamson River water increased with wind speed, whereas the partial replacement rate of water in Tulana with Williamson River water decreased with wind speed. Thus, stronger wind forcing at the water surface caused more of the Williamson River inflow to pass through Goose Bay than through Tulana. The Goose Bay partial replacement rate increased as the magnitude of the wind component from either the west or north increased, whereas the Tulana partial replacement rate had the opposite dependence. Therefore, westerly to northwesterly winds, which are the prevailing winds during the spring and summer months, result in more of the Williamson River inflow passing through the Goose Bay side of the Delta than through the Tulana side.

The use of the regression models for estimating the total and partial replacement rates was illustrated with two examples in which spring and summer conditions were assumed. In the first example, under the assumed springtime conditions, most of the Williamson River discharge was expected to flow through the Goose Bay side of the Delta. The theoretical time it would take to replace the water in Goose Bay, if the assumed meteorological conditions remained constant, provided an estimate of the residence time in Goose Bay of passively transported larvae. In the second example under the assumed summer conditions, measured summer benthic fluxes of orthophosphate from Tulana soils were used to estimate the steady-state contribution of Tulana soils to the concentration of orthophosphate in the overlying water column.

The utility of the regression models could be improved by running more experiments at different combinations of flow, lake elevation, and wind. The range of lake elevation used in the tracer experiments was between 4,140.5 and 4,142.5 feet, but exchange between both sides of the Delta and the Williamson River was strongly curtailed at an elevation between 4,140.5 and 4,141.5 feet that could not be precisely determined given the limited number of elevations used. The range of Williamson River inflow used in the tracer experiments was between 530 and 3,531 cubic feet per second. The range of wind conditions considered was limited to winds with a positive east-west component.

The results presented here provide insight into how movement of water through the Delta responds to hydrology as defined by the lake elevation and Williamson River inflow, and to wind forcing conditions at the lake surface. The regression equations provide a quick and easy-to-use means of making rough estimates of how fast water moves through both sides of the Delta and how the water entering the Delta at the Williamson River might be partitioned between Goose Bay and Tulana under varying conditions. 


\section{Acknowledgments}

This report was funded by the Bureau of Reclamation, U.S. Department of the Interior, as part of Bureau of Reclamation's mission to manage, develop, and protect water and related resources in an environmentally and economically sound manner in the interest of the American public. Funding was provided through Interagency Agreement 08AA200098. Additional funding was provided by the U.S. Geological Survey.

\section{References Cited}

Casulli, Vincenzo, 1999, A semi-implicit finite difference method for non-hydrostatic, free-surface flows:

International Journal for Numerical Methods in Fluids, v. 30 , p. $425-440$.

Casulli, Vincenzo, and Cheng, R.T., 1992, Semi-implicit finite difference methods for three-dimensional shallow water flow: International Journal for Numerical Methods in Fluids, v. 15, p. 629-648.

Casulli, Vincenzo, and Zanolli, Paola, 2002, Semi-implicit numerical modeling of nonhydrostatic free surface flows for environmental problems: Mathematical and Computer Modelling, v. 36, p. 1131-1149.

Casulli, Vincenzo, and Zanolli, Paola, 2005, High resolution methods for multidimensional advection-diffusion problems in free-surface hydrodynamics: Ocean Modelling, v. 10, p. 137-151.

Daraio, J.A., Randle, T.J., and Bach, L.B., 2004, Lower Williamson River Floodplain and Delta RestorationHydraulic modeling: Denver, Colo., U.S. Bureau of Reclamation Technical Service Center, 89 p.

DHI Water and Environment, 2002, MIKE 21 Coastal hydraulics and oceanography hydrodynamic module reference manual: Horsholm, Denmark, DHI Water and Environment, $58 \mathrm{p}$.

Ellsworth, C.M., Tyler, T.J., VanderKooi, S.P., and Markle, D.F., 2008, Patterns of larval catostomid emigration from the Sprague and lower Williamson Rivers of the Upper Klamath Basin, Oregon, prior to the removal of Chiloquin Dam-2004-2005 Annual Report: Klamath Falls, Oreg., prepared for the Bureau of Reclamation Mid-Pacific Region Klamath Area Office by U.S. Geological Survey, 45 p.
Ellsworth, C.M., Tyler, T.J., VanderKooi, S.P., and Markle, D.F., 2009, Patterns of larval sucker emigration from the Sprague and lower Williamson Rivers of the Upper Klamath Basin, Oregon, prior to the removal of Chiloquin Dam-2006 annual report: U.S. Geological Survey OpenFile Report 2009-1027, 32 p. (Also available at http://pubs. usgs.gov/of/2009/1027/.)

Graham Matthews and Associates, 2001, Geomorphic and hydraulic analysis of the Williamson River Restoration Project-Year 2000 riverbend site: Weaverville, Calif., prepared for The Nature Conservancy of Oregon, Portland, Oreg., 31 p.

Kuwabara, J.S., Topping, B.R., Carter, J.L., Parchaso, F., Asbill, J.R., Cameron, J.M., Asbill, J.R., Fend, S.V., Duff, J.H., and Engelstad, A.C., 2010, The transition of benthic nutrient sources after planned levee breaches adjacent to Upper Klamath and Agency Lakes, Oregon: U.S. Geological Survey Open-File Report 2010-1062, 31 p. (Also available at http://pubs.usgs.gov/of/2010/1062/.)

SAS Institute Inc., 2004, SAS/IML 9.1: Cary, North Carolina, SAS Institute Inc.

U.S. Geological Survey, 2011, USGS surface-water data for Oregon: U.S. Geological Survey water-database, accessed August 5, 2011, at http://waterdata.usgs.gov/or/nwis/sw/.

Wilks, D.S., 1995, Statistical methods in the atmospheric sciences: Academic Press, 467 p.

Wood, T.M., 2009, Preliminary study of the effect of the Long Lake Valley project operation on the transport of larval suckers in Upper Klamath Lake, Oregon: U.S. Geological Survey Open-File Report 2009-1060, 24 p. (Also available at http://pubs.usgs.gov/of/2009/1060/.)

Wood, T.M., Cheng, R.T., Gartner, J.W., Hoilman, G.R., Lindenberg, M.K., and Wellman, R.E., 2008, Modeling hydrodynamics and heat transport in Upper Klamath Lake, Oregon, and implications for water quality: U.S. Geological Survey Scientific Investigations Report 2008-5076, 48 p. (Also available at http://pubs.usgs.gov/sir/2008/5076/.)

Wood, T.M., Hoilman, G.R., and Lindenberg, M.K., 2006, Water-quality conditions in Upper Klamath Lake, Oregon, 2002-04: U.S. Geological Survey Scientific Investigations Report 2006-5209, 52 p. (Also available at http://pubs.usgs. gov/sir/2006/5209/.) 


\section{Appendix A. Animations of Tracer Simulations}

Three animations accompany this report to illustrate the movement of the tracers for a single set of conditions: elevation of the lake at 4,141.5 ft, flow from the Williamson River at $25 \mathrm{~m}^{3} / \mathrm{s}$, and strong northwest winds as measured on May 22 . The purpose of the animations is to provide a visual aid to understanding the initialization of each tracer, how they move subsequently through the modeled system, and what the mass of each tracer within Tulana and Goose Bay represents. Animations are embedded in figure 5 and are also available at http://pubs.usgs.gov/sir/2012/5004/. 
Publishing support provided by the U.S. Geological Survey

Publishing Network, Tacoma Publishing Service Center

For more information concerning the research in this report, contact the Director, Oregon Water Science Center

U.S. Geological Survey

2130 SW 5th Avenue

Portland, Oregon 97201

http://or.water.usgs.gov 


\section{हू}

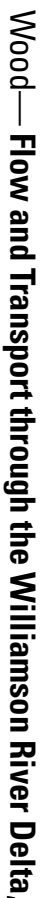

동

증

产

옹

is

ก.

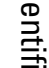

है

必

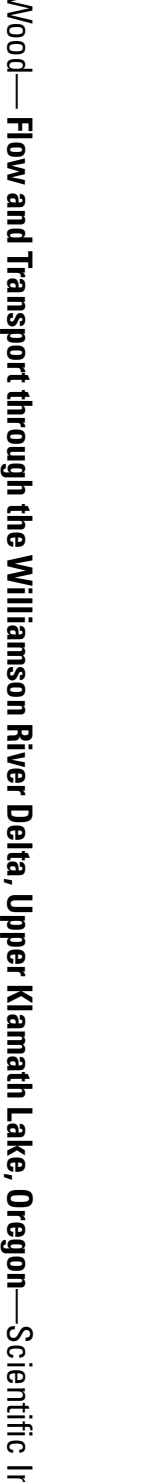

产.

궁

윽

怘

임

$\bigoplus$ Printed on recycled paper 